\title{
Physically-based modelling of hydrological processes in a tropical headwater catchment (West Africa) - process representation and multi-criteria validation
}

\author{
S. Giertz, B. Diekkrüger, and G. Steup \\ Institute of Geography, University of Bonn, Bonn, Germany \\ Received: 30 January 2006 - Published in Hydrol. Earth Syst. Sci. Discuss.: 28 April 2006 \\ Revised: 7 September 2006 - Accepted: 30 October 2006 - Published: 10 November 2006
}

\begin{abstract}
The aim of the study was to test the applicability of a physically-based model to simulate the hydrological processes in a headwater catchment in Benin. Field investigations in the catchment have shown that lateral processes such as surface runoff and interflow are most important. Therefore, the 1-D SVAT-model SIMULAT was modified to a semi-distributed hillslope version (SIMULAT-H). Based on a good database, the model was evaluated in a multi-criteria validation using discharge, discharge components and soil moisture data. For the validation of discharge, good results were achieved for dry and wet years. The main differences were observable in the beginning of the rainy season. A comparison of the discharge components determined by hydro-chemical measurements with the simulation revealed that the model simulated the ratio of groundwater fluxes and fast runoff components correctly. For the validation of the discharge components of single events, larger differences were observable, which was partly caused by uncertainties in the precipitation data. The representation of the soil moisture dynamics by the model was good for the top soil layer. For deeper soil horizons, which are characterized by higher gravel content, the differences between simulated and measured soil moisture were larger.

A good agreement of simulation results and field investigations was achieved for the runoff generation processes. Interflow is the predominant process on the upper and the middle slopes, while at the bottom of the hillslope groundwater recharge and - during the rainy season - saturated overland flow are important processes.
\end{abstract}

Correspondence to: S. Giertz

(sgiertz@uni-bonn.de)

\section{Introduction}

In the past decades significant progress has been achieved in understanding and modelling hydrological processes. The bulk of hydrological process research was carried out in temperate climate zones while only a few field investigations concerning hydrological processes were effected in tropical zones. Bonell and Bruijnzeel (2005) summarize the research activities concerning hydrology in the humid tropics with special regard to human activities. Their publication show that most investigations concerning runoff generation processes in tropical forests were carried out in South and Central America, Australia and South-East Asia. Particularly in the Amazon catchment in Brazil intensive process studies were performed by Elsenbeer et al. (1992), Elsenbeer and Lack (1996), Sobieraj et al. (2002) and Elsenbeer and Vertessy (2000). Most studies in the humid tropics revealed that lateral processes - mainly subsurface stormflow (interflow) - are predominant in tropical forest ecosystems. In West Africa, only a few studies concerning hydrological processes - particularly in Nigeria and the Ivory Coast- were carried out (Jeje et al., 1986; Ogunkoya and Jenkins, 1993; Chevallier and Planchon, 1993; van de Giesen et al., 2000).

Due to the limited data availability in West Africa, the amount of experience with hydrological modelling is relatively low. Often conceptual models with low input data requirements are used, because a parameterization of physically-based models is not feasible with the available data. Examples of successfully applied conceptual hydrological models include the utilization of the HBV-model in Senegal of Andersen et al. (2001), investigations with the conceptual UHP-model in Benin (Bormann and Diekkrüger, 2004) and a TOPMODEL-application in Nigeria (Campling et al., 2002). The first application of an intermediate approach between a conceptual and a physically-based model was presented by Varado (2004) for the Donga catchment in central Benin, but the development of the model was not

Published by Copernicus GmbH on behalf of the European Geosciences Union. 


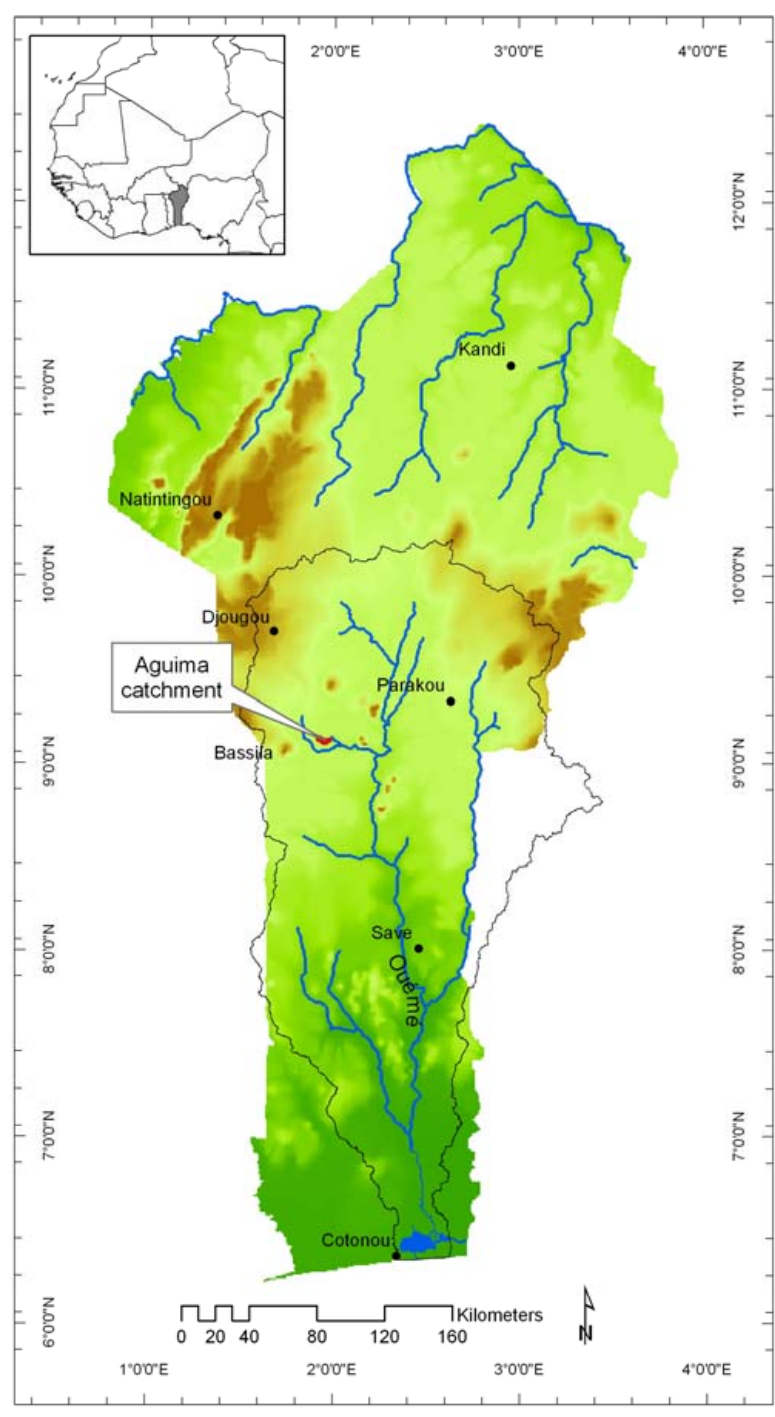

Fig. 1. Location of the Aguima catchment, a sub-catchment of the Ouémé river in Benin, West Africa.

finished. In other humid tropical regions such as South America, physically-based hydrological models have been successfully applied by Vertessy and Elsenbeer (1999) and Vertessy et al. (2000). This study is part of the IMPETUSproject (Speth et al., 2002), which analyses the impact of Global Change on the water cycle in Benin and Morocco.

The aim of this study was to test the applicability of the physically-based model SIMULAT-H in simulating the hydrological processes in the sub-humid tropical environment of West Africa with special regard to the process description. The process knowledge obtained by field studies was used to enhance the model which was intensely tested using field data. The objective was to thoroughly understand the hydrological processes and the influencing factors in the target region so as to be able to forecast the effect of Global
Change on the water cycle. For this purpose the model must be able to consider the spatial distribution of soils and vegetation and their temporal dynamic. The runoff generation processes have to be studied carefully to be able to predict the ratio of slow and fast runoff components in Global Change scenarios, which imply land use and climate change.

Based on field studies of the hydrological processes, the model results were evaluated with special regard to the process description. In order to analyse the effects of land cover on the runoff generation processes two sub-cachments with different land cover were investigated in detail (Upper Niaou: agricultural land use, Upper Aguima: natural vegetation).

\section{Study site}

In this study different sub-catchments of the Aguima catchment $\left(30 \mathrm{~km}^{2}\right)$, which is located in central Benin (Fig. 1), were investigated. The Aguima catchment was intensively investigated in terms of hydrology (Giertz, 2004), hydrogeology (Fass, 2004), soil properties and soil degradation (Junge, 2004), vegetation (Orthmann, 2005) and agriculture (Mulindabigwi, 2005; Dagbenonbakin, 2005) within the IMPETUS-project (Speth et al., 2002). Therefore a sufficient database for model parameterization and validation was available.

The catchment is located in the sub-humid Sudan-GuineaZone, which is characterized by a unimodal rainy season from May to October. The mean annual precipitation of the region is $1100 \mathrm{~mm}$ while the mean temperature is $26.4^{\circ} \mathrm{C}$. Typically monsoonal rainfall with a long duration and low intensities are of minor importance in the study area. Most of the precipitation comes from squall lines which results in a short period of high intensive rainfall followed by a longer tail with low intensities. Because the origin of the rainfall is the Jos plateau in Nigeria, the severe rainfall arrives at night when the measurement of the discharge is dangerous. Therefore, for peak flows, only water level measurements are available.

River discharge occurs periodically during the rainy season, while from December to May the rivers dry out. In small rivers, the time between the peak of rainfall and the peak of discharge is extremely short. Riverbank overflow discharge is common, resulting in problems concerning the stage-discharge relationship. Because the actual evapotranspiration is about $800 \mathrm{~mm} / \mathrm{yr}$, the total discharge is only about $20 \%$ of the precipitation.

The main soil types of the catchment are Lixisols and Acrisols according to the World Reference Base classification (ISSS Working Group RB, 1998). Geomorphology in the catchment is characterized by a flat, undulating pediplain relief with altitudes from 255 to $333 \mathrm{~m}$ above sea level. The underlying rock is migmatite, which is weathered to clayey saprolite. Swampy depressions, called inland valleys, can be found in the headwater catchment. These landscape features 
Table 1. Size and vegetation of the investigated sub-catchments.

\begin{tabular}{llll}
\hline Name of the sub-catchment & Upper Aguima & Lower Aguima & Upper Niaou \\
\hline Size of the sub-catchment $\left[\mathrm{km}^{2}\right]$ & 3.2 & 16.5 & 3.1 \\
\hline Land cover of the catchments [\%] & & & \\
\hline Woodland & 64.7 & 61.1 & 31.2 \\
Savannah & 29.7 & 31.2 & 32.1 \\
Fallow/cashew or teak plantation & 0.4 & 1.6 & 13.5 \\
Field & 3.1 & 5.6 & 23.2 \\
Inselberg & 2.1 & 0.5 & 0.0 \\
\hline
\end{tabular}

are the primary drainage system of the African Precambrian basement complex and can often be found on deeply weathered granite and metamorphic rocks. As is often seen in West Africa, two aquifers do exist. A fractured rock aquifer is found in depths below $20 \mathrm{~m}$. Near the surface a shallow saprolite aquifer is observed with a fluctuating groundwater level depending to the rainfall pattern. The latter aquifer is often used for water supply and is replenished during the rainy season.

The vegetation is mainly composed of woodland and savannah. The land use in the southern part of the catchment is predominantly agricultural.

To analyse the processes as well as to develop and to validate the hydrological model, three sub-catchments were taken into account. These sub-catchments are characterized by different land cover types (Table 1). Due to its location close to a small village, the Niaou catchment is more intensively used for agriculture. The pedological investigations of Giertz and Diekkrüger (2003), Junge (2004), Giertz (2004) and Giertz et al. (2005) revealed that the human impact has a strong influence on soil properties and hydrology of the catchment.

The instrumentation and the available data-sets of the catchment are described in Sect. 5.

\section{Hydrological processes}

The runoff generation processes are mainly determined by soil properties and land cover. In the following section the soil properties of a typical soil catena of the Upper Aguima and the Upper Niaou catchment are described.

According to Junge (2004) Lixisols and Acrisols are the prevailing soils in both catchments. They mainly occur on the middle part of the hillslope. These soils are characterized by loamy sand in the ochric horizon, by clay accumulation in an argic horizon and by plinthitic gravel as evidence of the accumulation of iron compounds. The shallow Plinthosol occurs near the drainage divide and at the bottom of the hillslope. They are defined by a subsurface layer containing an iron-rich mixture of clay minerals (chiefly kaolinite) and sil-

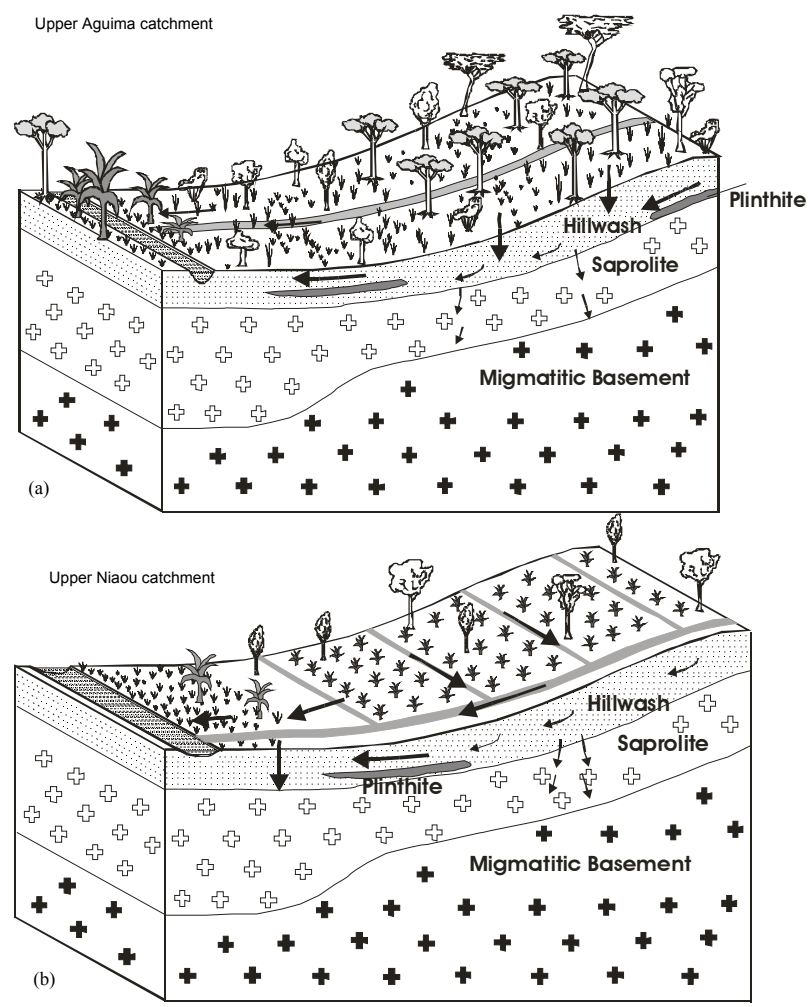

Fig. 2. Flow paths on representive hillslopes in the (a) Upper Aguima catchment (natural vegetation) and (b) in the Upper Niaou catchment (agriculture). The size of the arrows determines the importance of the flow paths.

ica that hardens on exposure into in impermeable ironstone crust. This crust occurs mostly at 30 to $60 \mathrm{~cm}$ depth, which depends on erosion and accumulation processes. The texture of the topsoil layer is loamy sand.

The Gleysols are predominant in inland valleys. Regarding soil physical properties two types of Gleysols can be distinguished in the area of investigation. At the border of the inland valleys the sandy Gleysol is the main soil type, while in the centre often soils with a clayey texture are prevalent. 
Table 2. Runoff generation processes in the Upper Aguima and Upper Niaou catchments.

\begin{tabular}{|c|c|c|}
\hline Hillslope, soil type & $\begin{array}{l}\text { Prevailing runoff generation processes } \\
\text { Upper Aguima, natural vegetation }\end{array}$ & $\begin{array}{l}\text { Prevailing runoff generation processes } \\
\text { Upper Niaou, } \\
\text { agricultural land use }\end{array}$ \\
\hline Upper hillslope, Plinthosol & Interflow & - \\
\hline Upper/middle hillslope, Lixisol & Groundwater flow (saprolite), interflow & $\begin{array}{l}\text { Surface runoff (dependent on land use), } \\
\text { groundwater flow (saprolite), interflow }\end{array}$ \\
\hline Lower hillslope, Plinthosol & Interflow & Surface runoff, interflow \\
\hline Inland valley fringe, sandy Gleysol & Groundwater flow & $\begin{array}{l}\text { Infiltration of surface runoff from hillslope } \\
->\text { high groundwater recharge (saprolite) }\end{array}$ \\
\hline Inland valley center, clayey Gleysol & Saturated surface runoff, groundwater flow & Saturated surface runoff, groundwater flow \\
\hline Pathways & Surface runoff & Surface runoff \\
\hline
\end{tabular}

Table 3. Water balance of the investigated catchments of the years 2000 to 2003.

\begin{tabular}{|c|c|c|c|}
\hline & Upper Aguima & Lower Aguima & Upper Niaou \\
\hline \multicolumn{4}{|c|}{2001 (18 June 2001-31 Dec 2001) } \\
\hline Precipitation $[\mathrm{mm}]$ & 609 & 609 & 609 \\
\hline Discharge volume $\left[\mathrm{m}^{3}\right]$ & 74145 & 752415 & 483054 \\
\hline Discharge height $[\mathrm{mm}]$ & 23.0 & 45.5 & 155.8 \\
\hline Discharge coefficient [\%] & 3.8 & 7.5 & 25.6 \\
\hline \multicolumn{4}{|l|}{2002} \\
\hline Precipitation [mm] & 1145 & 1145 & 1157 \\
\hline Discharge volume $\left[\mathrm{m}^{3}\right]$ & 351633 & 2323637 & 568804 \\
\hline Discharge height [mm] & 109.2 & 139.6 & 183.5 \\
\hline Discharge coefficient [\%] & 9.5 & 12.2 & 15.8 \\
\hline \multicolumn{4}{|l|}{2003} \\
\hline Precipitation [mm] & 1216 & 1216 & 1230 \\
\hline Discharge volume $\left[\mathrm{m}^{3}\right]$ & 631473 & 3033868 & 714710 \\
\hline Discharge height [mm] & 196.1 & 183.3 & 230.6 \\
\hline Discharge coefficient [\%] & 16.1 & 15.2 & 18.7 \\
\hline
\end{tabular}

In the riparian zone the Fluvisol, composed of alluvial sands, is the predominating soil type.

Although the texture of the top-soil of the different soil types is relatively uniform (mostly loamy sand), the in-situ measurements of the saturated conductivity revealed a high variability. The differences are mainly caused by different land use, which strongly influences the soil physical properties (e.g. macroporosity due to biological activity), as was shown by Giertz (2004), Giertz et al. (2005) and Junge (2004). These investigations revealed that on savannah plots a mean density of 219 macropores $/ \mathrm{m}^{2}$ was observable, and only 5 (cotton), 8 (yam) and 60 (maize) macropores $/ \mathrm{m}^{2}$ existed on agricultural fields (Giertz et al., 2005). The impact of the macroporosity on the infiltration process was shown by in-situ measurements of the saturated conductivity. On agricultural fields the $\mathrm{K}_{\text {sat }}$-value was two to five times (de- pending on soil type) lower than on savannah/woodland vegetation. Therefore for the surface runoff generation process the land use is one of the most important factors.

The runoff generation processes in the subsoil is more related to the soil types, as the soil physical properties vary strongly between them. The permeability of the subsoil is relatively low for Lixisols/Acrisols (mean: $21.1 \mathrm{~cm} / \mathrm{d}$ ) and especially for Plinthosols with the nearly impermeable ironpan crust (Giertz, 2004).

Based on the soil investigation and the land use types, the prevalent runoff generation processes for the hillslope units of the two catchments can be characterized as listed in Table 2. Figure 2 shows the flow paths for the Upper Aguima and the Upper Niaou catchment as derived from the soil investigations, hydrogeological investigations from Fass (2004) and field observations. In the Upper Aguima 
(a)

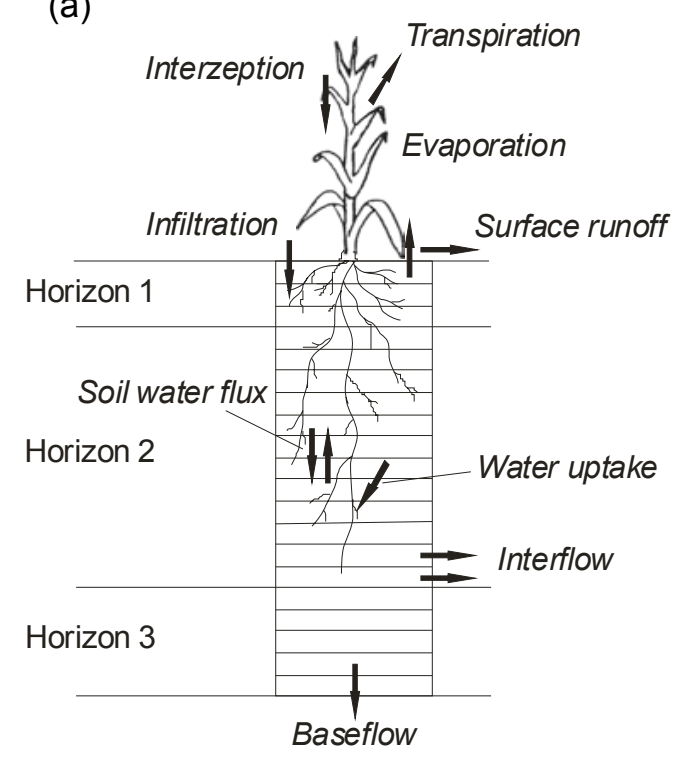

(b)

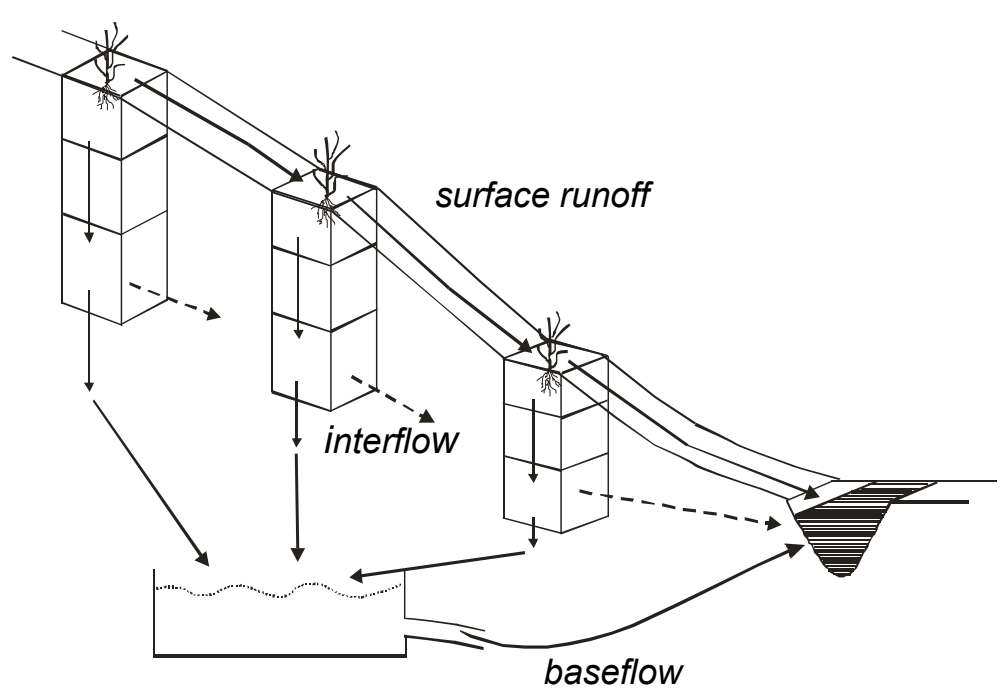

Fig. 3. (a) Model concept of SIMULAT. (b) Modification of SIMULAT to the hillslope version SIMULAT-H.

catchment surface runoff occurs only on pathways (Hortonian overland flow) or at the bottom of the hillslope (saturated overland flow), when the inland valley is saturated during the rainy season. But as inland valleys only occur at $1 / 3$ of the channel length of the Upper Aguima, this process is not as important as in the Upper Niaou, where the whole river is characterized by inland valleys (Giertz and Diekkrüger, 2003). Due to the high macroporosity in soils of natural savannah and woodland vegetation, the infiltration rates are very high. The low permeability of the subsoil of Lixisols and Plinthosols results in subsurface flow processes, which can be considered as the prevailing processes on the hillslopes. In the Upper Niaou catchment the amount of surface runoff is higher due to low infiltration rates on fields. The generated surface runoff turns into concentrated flow on pathways and infiltrates at the bottom of the hillslope in the sandy Gleysol at the border of the inland valley. This process contributes to the saturation of the inland valley during the rainy season. After saturation of this area, saturated overland flow occurs.

Due to higher surface runoff amounts and lower evapotranspiration (Giertz et al., 2005) the discharge amount is higher in the agricultural catchment, which is shown in Table 3. Mainly in dry years like the year 2001 the differences between the catchments with natural vegetation and with agricultural land use is high.

\section{Model approach}

The analysis of the hydrological processes revealed that lateral processes as interflow and surface runoff are the major runoff generation processes in the catchment. Consequently the incorporation of lateral flow processes into the modelling approach is essential for an adequate process description.

To simulate the hydrological processes, the physicallybased 1-D SVAT-model SIMULAT (Diekkrüger and Arning, 1995) was modified to a hillslope version SIMULAT-H. The model structure of the 1-D-model and the modified model is shown in Figs. 3a and b.

In SIMULAT-H, hillslope processes are taken into account. The hillslope is subdivided in a number of subunits. The simulated surface runoff of the upslope unit is considered as additional water input at the soil surface on the downslope subunit.

The algorithms to calculate the evapotranspiration, soil water fluxes and the lower boundary condition are taken from the 1-D-model SIMULAT. In the following sections the algorithms of the major processes are described. The complete model description can be found in Giertz (2004).

To simulate base flow, a conceptual, linear groundwater model was linked to SIMULAT-H. Because no overland flow routing was integrated in SIMULAT-H, the discharge is simulated as the superposition of the single runoff components. Because validation was performed at a daily time step and the reaction time is within hours this simplification is assumed to be acceptable. 


\subsection{Evapotranspiration}

In this section the following terms are used:

\begin{tabular}{|c|c|c|}
\hline $\mathrm{ET}_{\text {pot }}$ & $=$ & potential evapotranspiration $\left[\mathrm{kg}\left(\mathrm{m}^{2} \mathrm{~s}\right)^{-1}\right]$ \\
\hline$\Delta$ & $=$ & $\begin{array}{l}\text { slope of the saturation vapour } \\
\text { pressure temperature relationship [-] }\end{array}$ \\
\hline$\lambda$ & $=$ & latent heat of vaporisation $\left[\mathrm{J} \mathrm{kg}^{-1}\right]$ \\
\hline $\mathrm{c}_{p}$ & $=$ & specific heat of the air $\left[1005 \mathrm{~J}(\mathrm{~kg} \mathrm{~K})^{-1}\right]$ \\
\hline$\left(\mathrm{e}_{s}-\mathrm{e}_{a}\right)$ & $=$ & vapour pressure deficit of the air $[\mathrm{hPa}]$ \\
\hline$\gamma$ & $=$ & psychrometric constant $\left[0.68 \mathrm{hPa} \mathrm{K}^{-1}\right]$ \\
\hline $\mathrm{r}_{S}$ & $=$ & bulk-stomata resistance $\left[\mathrm{s} \mathrm{m}^{-1}\right]$ \\
\hline $\mathbf{r}_{a}$ & $=$ & aerodynamical resistance $\left[\mathrm{s} \mathrm{m}^{-1}\right]$ \\
\hline $\mathrm{R}_{n}$ & $=$ & radiation balance $\left[\mathrm{W} \mathrm{m}^{-2}\right]$ \\
\hline G & $=$ & soil heat flux $\left[\mathrm{W} \mathrm{m}^{-2}\right]$ \\
\hline LAI & $=$ & leaf area index $[-]$ \\
\hline $\mathrm{E}_{\mathrm{pot}}$ & $=$ & potential evaporation $\left[\mathrm{kg}\left(\mathrm{m}^{2} \mathrm{~s}\right)^{-1}\right]$ \\
\hline $\mathrm{E}_{\text {act }}$ & $=$ & actual evaporation $\left[\mathrm{kg}\left(\mathrm{m}^{2} \mathrm{~s}\right)^{-1}\right]$ \\
\hline $\mathrm{E}_{\max }$ & $=$ & maximum evaporation $\left[\mathrm{kg}\left(\mathrm{m}^{2} \mathrm{~s}\right)^{-1}\right]$ \\
\hline$\xi$ & $=$ & soil factor $[-]$ \\
\hline i & $=$ & days since a defined minimal precipitation $[\mathrm{d}]$ \\
\hline $\mathrm{T}_{\text {pot }}$ & $=$ & potential transpiration $\left[\mathrm{kg}\left(\mathrm{m}^{2} \mathrm{~s}\right)^{-1}\right]$ \\
\hline$\tau(\psi, \mathrm{z})$ & $=$ & reduction factor $[-]$ \\
\hline$\psi_{1}$ & $=$ & $\begin{array}{l}\text { minimal matrix potential, where water uptake } \\
\text { of the roots occurs }[\mathrm{hPa}]\end{array}$ \\
\hline$\psi_{2}$ & $=$ & $\begin{array}{l}\text { matrix potential, where a reduction of the } \\
\text { water uptake of the roots starts }[\mathrm{hPa}]\end{array}$ \\
\hline$\psi_{3}$ & $=$ & wilting point $[\mathrm{hPa}]$ \\
\hline
\end{tabular}

The potential evapotranspiration is calculated with the Penman-Monteith equation:

$\lambda E T_{\mathrm{pot}}=\frac{\Delta\left(R_{n}-G\right)+c_{\rho} \frac{e_{s}-e_{a}}{r_{a}}}{\Delta+\gamma\left(1+\frac{r_{s}}{r_{a}}\right)}$

In order to calculate the actual evapotranspiration the potential evapotranspiration is primarily separated in evaporation $\left(\mathrm{E}_{\mathrm{pot}}\right)$ and transpiration $\left(\mathrm{T}_{\mathrm{pot}}\right)$ based on the leaf-area index (Ritchie, 1972):

$$
\begin{aligned}
& E_{\mathrm{pot}}=E T_{\mathrm{pot}} e^{-0.4 \mathrm{LAI}} \\
& T_{\mathrm{pot}}=E T_{\mathrm{pot}}\left(1-e^{-0.4 \mathrm{LAI}}\right)
\end{aligned}
$$

The actual evaporation is computed with the empirical approach of Ritchie (1972). Two cases are distinguished:

1. Until the maximum of evaporation $\left(E_{\max }\right)$ is achieved the actual evaporation is equal to the potential evaporation

2. After the attainment of $E_{\max }$ the actual evaporation declines continuously with time. The soil factor $\xi$, which depends on the clay content of the soil, determines the decrease rate of the actual evaporation.

$$
\begin{aligned}
& E_{\mathrm{act}}=\left\{\begin{array}{l}
E_{\mathrm{pot}} \text { for } E_{\mathrm{pot}}<E_{\max } \\
E_{\mathrm{max}} \text { for } E_{\mathrm{pot}} \geq E_{\max }
\end{array}\right. \\
& E_{\max }=\left\{\begin{array}{cc}
\xi\left(\sqrt{i}-\sqrt{i-1} \text { if } \sum E>9(\xi-3)^{0.42}\right. \\
\infty & \text { if } \sum E \leq 9(\xi-3)^{0.42}
\end{array}\right.
\end{aligned}
$$

To determine the actual transpiration the approach of Feddes et al. (1978) is implemented in SIMULAT. The potential transpiration $\mathrm{T}_{\mathrm{pot}}$ is reduced by the factor $\tau$, which is calculated depending on the matrix potential.

$\tau(\psi, z)=\left\{\begin{array}{cl}0 & \text { for } \psi>\psi_{1} \vee \psi \leq \psi_{3} \\ 1 & \text { for } \psi \leq \psi_{1} \wedge \psi \geq \psi_{2} \\ \frac{\psi-\psi_{3}}{\psi_{2}-\psi_{3}} & \text { for } \psi<\psi_{2} \wedge \psi>\psi_{3}\end{array}\right.$

\subsection{Infiltration and surface runoff}

The infiltration rate is computed with a semi-analytical solution of the Richard's equation based on Smith and Parlange (1978):

$f=K_{\mathrm{sat}} \frac{e^{F / B}}{e^{F / B}-1}$

With $B$ definded as:

$$
B=G\left(\theta_{s}-\theta_{i}\right)
$$

with

$$
\begin{aligned}
\mathrm{f} & =\text { infiltration rate }\left[\mathrm{cm} \mathrm{d} \mathrm{d}^{-1}\right] \\
\mathrm{F} & =\text { cumulative infiltration }[\mathrm{cm}] \\
\mathrm{G} & =\text { capillary drive }[\mathrm{hPa}] \\
\theta_{s} & =\text { saturated water content }\left[\mathrm{cm}^{3} \mathrm{~cm}^{-3}\right] \\
\theta_{i} & =\text { initial soil water content }\left[\mathrm{cm}^{3} \mathrm{~cm}^{-3}\right] \\
\mathrm{K}_{\mathrm{sat}} & =\text { effective saturated hydraulic conductivity } \\
& {\left[\mathrm{cm} \mathrm{d} \mathrm{d}^{-1}\right] }
\end{aligned}
$$

In order to take into account the high variability of the saturated conductivity, a log-normal distribution of the $\mathrm{K}_{\text {sat }}$ values is considered. A certain number of $\mathrm{K}_{\mathrm{sat}}$-values are chosen using the Latin-Hypercube method (MacKay et al., 1979). For the determined values the Smith-Parlange equation (Eq. 5) is calculated. The mean of all calculations is considered as infiltration rate of the soil matrix.

\subsection{Soil water fluxes}

In this section the following terms are used:

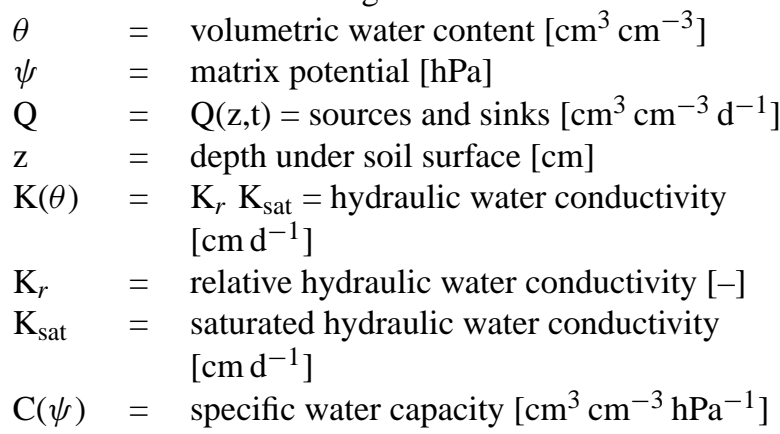

The soil water fluxes are calculated based on Richards's equation:

$C(\psi) \frac{\partial \psi}{\partial t}=\frac{\partial}{\partial z}\left(K(\theta) \frac{\partial}{\partial z}(\psi-z)\right)+Q$

For the mathematical description of the soil-water-retention curve the approach of Brooks and Corey (1964) is used. 


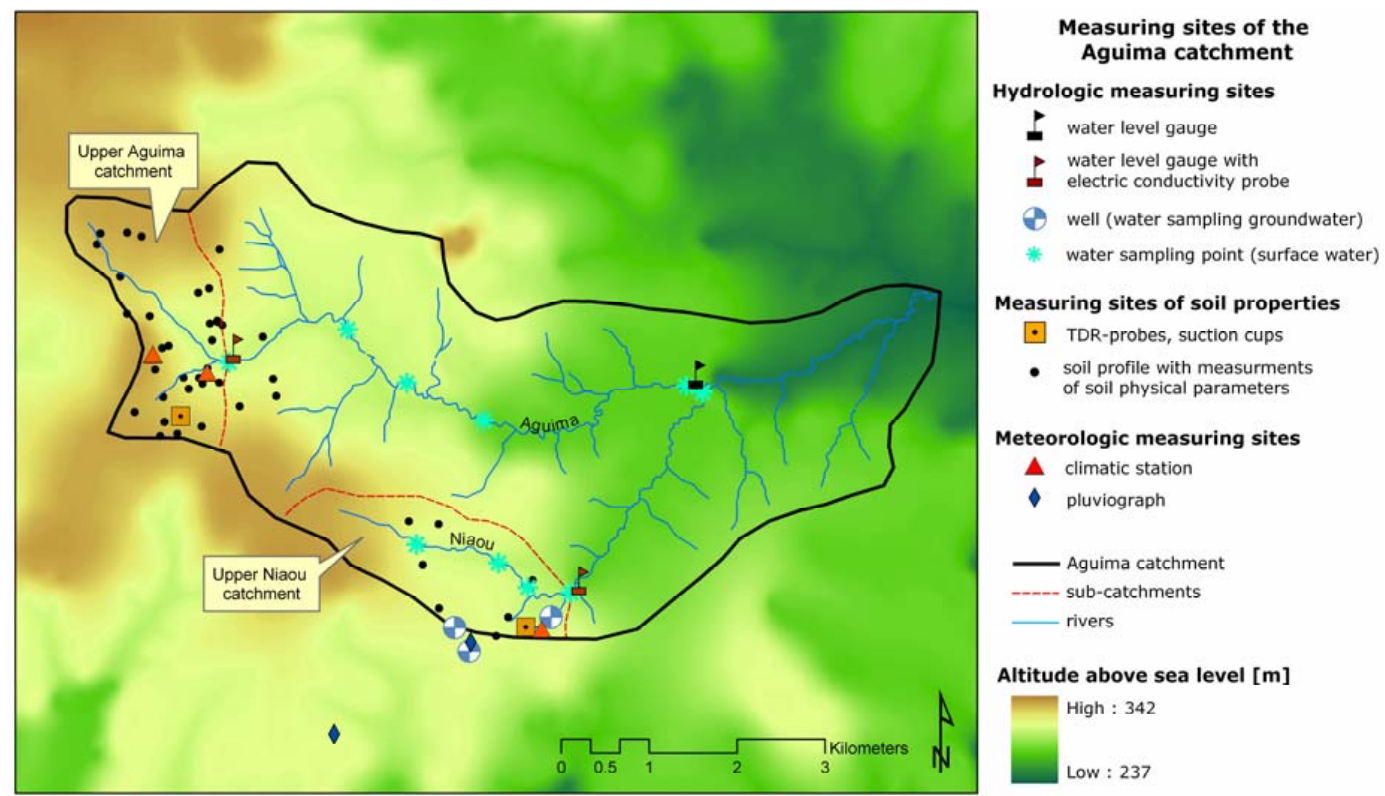

Fig. 4. Instrumentation of the Aguima catchment.

\section{Interflow}

The interflow is considered as a sink in the Richard's equation. The lateral flow is the product of the lateral conductivity $\mathrm{K}_{\text {sat,lat }}$ and the slope $\alpha$ :

$q_{l}=K_{\text {sat }, \text { lat }} \cdot \sin (\alpha)$ for $\psi>0$

with

$$
\begin{aligned}
& \mathrm{q}_{l} \quad=\quad \text { interflow }\left[\mathrm{cm}^{3} \mathrm{~cm}^{-3} \mathrm{~d}^{-1}\right] \\
& \mathrm{K}_{\text {sat,lat }}=\text { lateral saturated hydraulic water } \\
& \text { conductivity }\left[\mathrm{cm} \mathrm{d}^{-1}\right] \\
& \alpha \quad=\text { slope }[-]
\end{aligned}
$$

\section{Data base and model parameterization}

As mentioned in Sect. 2, intensive field studies were carried out in the Aguima catchment, therefore a reliable database to parameterize and validate the physically-based model was available. In Fig. 4 the measuring sites relevant for this study are shown.

\subsection{Model parameterization}

\subsubsection{Spatial discretization}

In order to apply SIMULAT-H according to the hillslope concept the catchment was discretized into hillslopes. This was performed with TOPAZ (Topographic Parametrization Tool) (Garbrecht and Martz, 1997), a tool for terrain analysis. The determination of sub-catchments and hillslopes were based on the calculated flow direction which is determined with the D8-Method (Fairchild and Leymarie, 1991). The discretized

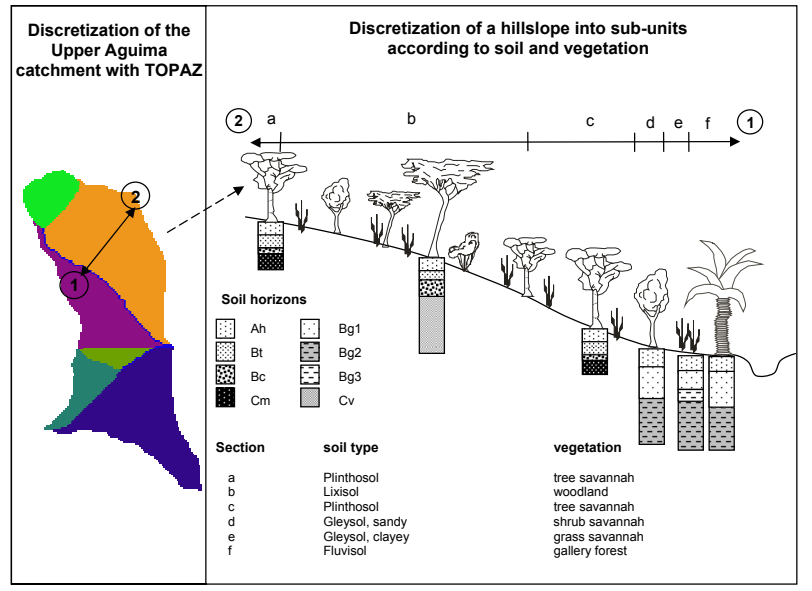

Fig. 5. Discretization of a representative hillslope of the Upper Aguima catchment.

hillslopes were subdivided into sub-units according to the soil units of the detailed soil map of Junge (2004). Figure 5 shows the discretization of the sub-catchment Upper Aguima into slopes and the subdivision into homogeneous soil units.

For the Upper Aguima and the Upper Niaou catchment all determined hillslopes were parameterized, while for the $16 \mathrm{~km}^{2}$ sized Lower Aguima catchment ten representative hillslopes were chosen from the total of 68 hillslopes. In order to derive the representative hillslopes a GIS-analysis was carried out taking into account the slope, the vegetation and the soil units. 
Field observations revealed that during extreme precipitation events a high quantity of surface runoff concentrates on small tracks and flows rapidly into the river. To simulate this process, the percentage of tracks in the catchment, which was mapped using a GPS, was considered as separate subunit with a low permeability. The surface runoff occurring on this subunit was added directly to the river discharge during the simulation process.

\subsubsection{Soil parameterization}

For each soil unit classified in the soil map of Junge (2004) two representative soil profiles (one in natural savannah, one in agricultural area) were chosen for the determination of soil physical properties. As SIMULAT-H enables a variable horizontal discretization of the soil columns the determination of the physical properties was carried out for each horizon of the representative soil profiles. In each horizon two soil cores were taken for the measurement of the soil-water-retention curve and four samples for the determination of the saturated conductivity. In addition in-situ measurements of saturated conductivity were carried out on plots close to the representative soil profiles. With the in-situ measurements a better representation of the soil surface characteristics was feasible. In order to take into account the spatial variability of the saturated conductivity at least eight measurements were conducted on each plot. Depended on soil unit and vegetation type the mean of the measured saturated conductivity was used for the parameterization of the soil of each hillslope unit.

\subsubsection{Vegetation parameters}

For each hillslope-unit several vegetation types can be defined. For each vegetation type interception, evapotranspiration and infiltration is calculated separately in the model. The water balance of the entire hillslope-unit is then calculated depending on the ratio of the vegetation type on the hillslope-unit.

Based on the classification of the Landsat 7 ETM+ image (Judex, 2003) the different vegetation types were allocated to the hillslope-units with GIS.

The vegetation parameters (LAI, vegetation height, root depth etc.) were mainly taken from measurements in the Aguima catchment in the framework of the IMPETUS project (Orthmann, 2005; Mulindabigwi, 2005). The measurements were conducted at different times during the years 2001 and 2002. Therefore the variation of these parameters during the year was also taken into account. In case of missing or implausible measuring data literature data from Cournac et al. (2002), de Wasseige et al. (2003) and Scourlock et al. (2001) were used for parameterization.

\subsubsection{Climatic data}

To obtain the required climate data for the model (temperature, relative humidity, wind velocity, global radiation and precipitation) the data of three climatic stations were available in the Aguima catchment (Fig. 4). Additionally data from two rain gauges outside the catchment were obtained. This data was used to fill up gaps in the precipitation data during periods where the climatic stations had failed.

\subsection{Validation data}

To validate the model, measurement data of discharge, discharge components and soil moisture were used. As the water level gauges were installed in June 2001 the discharge data were obtainable from 2001 to 2003.

The discharge components for single events were determined by measurements of electric conductivity at the river gauging station Upper Aguima and Upper Niaou. The measurements were performed during the rainy season of 2002 in a $10 \mathrm{~min}$ interval. Additionally, independent water analysis data of Fass (2004) was used to validate the discharge components. Fass (2004) analysed the hydrochemistry of water samples from different sources (rain water, river water, groundwater, soil water, saprolitic water) to determine the fraction of the different water types on the river discharge. The mixing-ratio of the river water was calculated with PHEREEQC-2 (Parkhurst and Appello, 1999) based on water samples taken during the rainy season of the years 2001 and 2002.

The soil moisture was measured with TDR-probes in four different depths $(0-20,30-50,80-100,120-140 \mathrm{~cm})$ with an automatic data logger system with a temporal resolution of $10 \mathrm{~min}$. Due to a failure of the measuring system, the soil moisture data was only available for 2001 and 2002.

\section{Sensitivity analysis}

The investigation concerning parameter sensitivity was performed for one representative slope of the Upper Aguima catchment. Mainly soil and vegetation parameters were taken into account.

To evaluate the sensitivity the sensitivity index $\mathrm{SI}_{10}$ was calculated according to de Roo (1993):

$$
\begin{aligned}
& S I_{10}=\frac{\left|\mathrm{O}_{P 10}-\mathrm{O}_{M 10}\right|}{\mathrm{O}_{o}} \\
& \text { with } \\
& \mathrm{O}_{P 10}=\begin{array}{l}
\text { model output with a } 10 \% \text { increase } \\
\text { of the parameter value }
\end{array} \\
& \mathrm{O}_{M 10}=\begin{array}{l}
\text { model output with a } 10 \% \text { reduction } \\
\text { of the parameter value } \\
\text { model output with base simulation }
\end{array}
\end{aligned}
$$


Table 4. Sensitivity indices $\mathrm{SI}_{10}$ for different model parameters calculated for a representative hillslope (in bold the most sensitive parameters).

\begin{tabular}{llllll}
\hline & $\begin{array}{l}\mathrm{SI}_{10} \\
\text { Total discharge }\end{array}$ & $\begin{array}{l}\mathrm{SI}_{10} \\
\text { Surface runoff }\end{array}$ & $\begin{array}{l}\mathrm{SI}_{10} \\
\text { Interflow }\end{array}$ & $\begin{array}{l}\mathrm{SI}_{10} \\
\text { Ground- } \\
\text { waterflow }\end{array}$ & $\begin{array}{l}\mathrm{SI}_{10} \\
\text { Evapotrans- } \\
\text { piration }\end{array}$ \\
\hline Soil parameter & & & & \\
\hline$\theta_{S}$ & $\mathbf{0 . 9 1 6 7}$ & 0.2468 & 0.7876 & $\mathbf{1 . 2 8 5 8}$ & 0.0084 \\
$\theta_{r}$ & 0.0479 & 0.0150 & 0.0339 & 0.0832 & 0.0158 \\
$\mathrm{~K}_{\text {sat }}$ & 0.0420 & 1.0563 & 0.0424 & 0.0834 & 0.0050 \\
$\mathrm{~K}_{\text {sat-lat }}$ & 0.0033 & 0.0000 & 0.0367 & 0.0704 & 0.00002 \\
$\mathrm{~K}_{\text {sat-sigma* }}$ & 0.0194 & 0.4868 & 0.0190 & 0.0372 & 0.0042 \\
\hline Vegetation parameter & & & & 0.0766 & 0.0228 \\
\hline LAI & 0.0826 & 0.0185 & 0.0889 & 0.4249 & 0.0044 \\
Stomata resistance & 0.2833 & 0.0551 & 0.2321 & 0.3566 & 0.0110 \\
Vegetation height & 0.0844 & 0.0169 & 0.0326 & 0.0370 & 0.0000 \\
Root depth & -0.0250 & 0.0425 & 0.0233 & & 0.0000 \\
\hline Groundwater parameter & & & 0.0320 & 0.0003 \\
\hline Gw-constant & 0.0030 & 0.0000 & 0.0099 & 0.0000 & \\
\hline Initial Gw-storage & 0.0001 & 0.0000 & & & \\
\hline
\end{tabular}

* $\mathrm{K}_{\text {sat-sigma }}$ : standard deviation of log-normal distribution of $\mathrm{K}_{\mathrm{sat}}$-values.

Table 4 shows the sensitivities for the chosen soil, vegetation and groundwater parameters with regard to discharge, discharge components and evapotranspiration.

The sensitivity analysis reveals that among the soil parameters the saturated water content is the most sensitive parameter concerning the total discharge and the groundwater flow. Regarding the vegetation parameters the stomata resistance is the most sensitive parameter.

\section{Calibration and validation of the model SIMULAT-H}

\subsection{Model performance criteria}

In order to evaluate the model performance for the calibration and the validation the following criteria were taken into account:

1. the coefficient of determination $\mathrm{r}^{2}$

2. the coefficient of model efficiency (Nash and Sutcliff, 1970)

3. the index of agreement (Willmott, 1981)

4. for the discharge validation: the difference between the simulated and measured annual discharge amount
The model efficiency according to Nash and Sutcliff (1970) is defined as:

$M E=\frac{\sum_{i=1}^{n}\left(x_{i}-\bar{x}\right)^{2}-\sum_{i=1}^{n}\left(x_{1}^{\prime}-x_{i}\right)^{2}}{\sum_{i=1}^{n}\left(x_{1}-\bar{x}\right)^{2}}$

$x_{i}=$ measured variable

$\bar{x}=$ arithmetic mean of $\mathrm{x}_{i}$ for all events, $\mathrm{i}=1$ to $\mathrm{n}$

$x_{i}^{\prime}=$ simulated variable

The model efficiency can attain values from $-\infty$ to 1 . The value of 1 indicates the total agreement of measured and simulated values.

In addition to $r^{2}$ and the model efficiency, which are usually used as objective functions for model validation, the index of agreement according to Willmott (1981) is applied. This index is a good indicator to evaluate the temporal representation of the discharge by the model. It is calculated with the following equation:

$I A=1-\frac{\sum_{i-1}^{n}\left(x_{i}-x_{i}^{\prime}\right)^{2}}{\sum_{i=1}^{n}\left(\left|x_{i}-\bar{x}^{\prime}\right|+\left|x_{i}^{\prime}-\bar{x}^{\prime}\right|\right)^{2}}$

The range of values of the index of agreement is between 0 and 1 , while 1 represents the total agreement of measured and simulated values. 


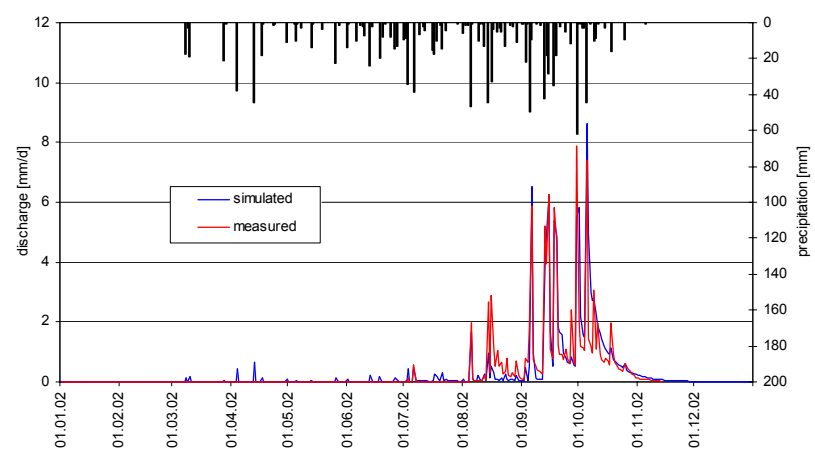

Fig. 6. Comparison of the simulated and measured hydrograph of the Upper Aguima catchment, year $2002\left(3.2 \mathrm{~km}^{2}\right.$, calibration result).

\subsection{Calibration of the model}

The model was manually calibrated for the year 2002 for the Upper Aguima catchment for the river discharge. As nearly all input parameters were determined by field measurements only the parameters of the conceptual groundwater model and the lateral $\mathrm{K}_{\text {sat-value were calibrated. The lateral satu- }}$ rated conductivity was not calibrated for each soil separately. Instead an overall reduction factor was determined in relation to the measured vertical $\mathrm{K}_{\text {sat }}$-value. The optimal factor was identified by comparing the measured and simulated hydrographs.

Figure 6 shows the result of the simulated hydrograph compared with the measured discharge. Only in the beginning of the discharge period major differences between measured and simulated discharge are observable. This is due to the fact that the runoff at the beginning of the rainy season infiltrates in the river bed and fills up the groundwater storage. Because the conceptual groundwater model is not spatially distributed, the infiltration of river discharge into groundwater can not be computed correctly. In the remaining period the agreement of the simulated and measured hydrographs is good. The discharge peaks as well as the recession period fit to the measured values. The model efficiency and the $\mathrm{r}^{2}$ attain 0.82 , while the index of agreement has a value of 0.95 . The total discharge is slightly overestimated by the model (109 $\mathrm{mm}$ measured, $117 \mathrm{~mm}$ simulated).

\subsection{Model validation}

Due to a good database, a multicriteria validation of the model was feasible. In addition to discharge data, discharge components and soil moisture data, which were not used for calibration, were available to validate the model results.

\subsubsection{Validation of discharge}

The validation of the model was performed with the split sample and the proxy basin test according to Refsgaard and Storm (1996).
Table 5. Model validation Lower Aguima catchment.

\begin{tabular}{llllll}
\hline & $\begin{array}{l}\text { Q measured } \\
{[\mathrm{mm}]}\end{array}$ & $\begin{array}{l}\text { Q simulated } \\
{[\mathrm{mm}]}\end{array}$ & $\mathrm{ME}$ & $\mathrm{r}^{2}$ & $\mathrm{IA}$ \\
\hline $2001^{*}$ & 45.5 & 47.4 & 0.82 & 0.82 & 0.95 \\
2002 & 139.6 & 132.5 & 0.86 & 0.87 & 0.96 \\
2003 & 183.3 & 254.7 & 0.64 & 0.67 & 0.87 \\
\hline
\end{tabular}

* Simulated period: 20 June 2001-31 December 2001.

For the proxy basin test the model was applied in the $16 \mathrm{~km}^{2}$ sized Lower Aguima catchment without further adjusting of parameters for 2002. For the split sample test the simulation was applied for the years 2001 and 2003 in the Upper and Lower Aguima and the Upper Niaou catchments.

Proxy basin test

The scatter plot in Fig. 7 shows the comparison of measured and simulated discharge on daily basis for the years 2001, 2002 and 2003. The criteria for the model performance of the simulated years are shown in Table 5. For the year 2002 the correspondence of the simulated and measured discharge is given in Fig. 8. There is a slight underestimation of the discharge amount for the whole year but the model efficiency and the $\mathrm{r}^{2}$ are even higher than for the calibration period (Table 5). Comparable to the calibration period the major differences between the measured and modelled hydrograph can be observed in the beginning of the discharge period where the baseflow is underestimated, while discharge peaks are often overestimated. In the middle of the rainy season the peaks as well as the baseflow are modelled well and also the recession of the discharge is simulated accurately.

\section{Split sample test}

The model was applied with the same parameter set for the years 2001 and 2003 to perform the split sample test for all considered catchments.

The diagram of the model validation in the Lower Aguima catchment for the year 2001 in Fig. 9 shows that the agreement of simulated and measured discharge is good. The discharge peak at the end of September and also the baseflow are simulated well in 2001. Due to the reason explained before, in the beginning of the rainy season small discharge peaks are simulated, although no discharge was measured at all. The model efficiency and the $\mathrm{r}^{2}$ are 0.82 , while an index of agreement of 0.95 is achieved. The measured discharge amount is slightly underestimated by the model $(2 \mathrm{~mm})$.

For 2003 (Fig. 10) the model performance is not as good as for 2001 and 2002. The comparison of simulated and measured discharge reveals that there is a strong overestimation of discharge events in June. Also the events of the 31 August 2003 and 2 October 2003 are overestimated by the model. 
Table 6. Model validation for the Upper Aguima and Upper Niaou catchments.

\begin{tabular}{llllll}
\hline \multicolumn{5}{c}{ Upper Aguima } \\
\hline & $\begin{array}{l}\text { Q measured } \\
{[\mathrm{mm}]}\end{array}$ & $\begin{array}{l}\text { Q simulated } \\
{[\mathrm{mm}]}\end{array}$ & ME & $\mathrm{r}^{2}$ & IA \\
\hline $2001^{*}$ & 23.0 & 40.2 & 0.67 & 0.78 & 0.87 \\
$2002 \mathrm{C}$ & 109.2 & 117.2 & 0.82 & 0.82 & 0.95 \\
2003 & 196.1 & 225.1 & 0.42 & 0.53 & 0.84 \\
\hline & \multicolumn{7}{c}{ Upper Niaou } & & & \\
\hline & Q measured & Q simulated & ME & $\mathrm{r}^{2}$ & IA \\
& {$[\mathrm{mm}]$} & {$[\mathrm{mm}]$} & & & \\
\hline $2001^{*}$ & 155.8 & 187.5 & 0.42 & 0.49 & 0.84 \\
2002 & 183.5 & 202.1 & 0.67 & 0.71 & 0.91 \\
2003 & 230.6 & 265 & 0.58 & 0.66 & 0.89 \\
\hline
\end{tabular}

* Simulated period: 20 June 2001-31 December 2001. C = Calibration period.

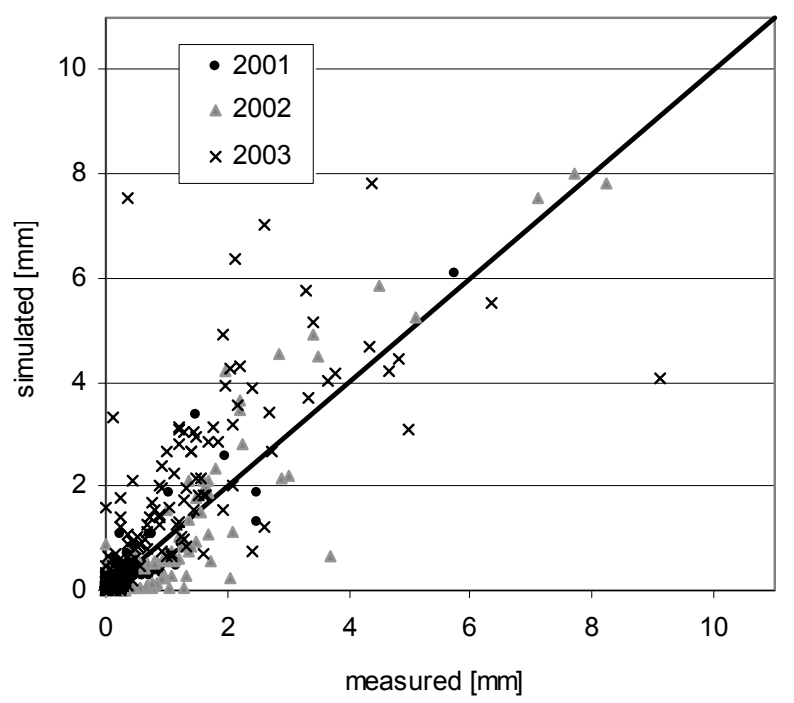

Fig. 7. Scatter plot of simulated and measured discharge for the Lower Aguima catchment (16.5 $\mathrm{km}^{2}$, validation results).

Due to a failure of the measuring system, the precipitation data for the climatic station within the Aguima catchment were not available for part of the year of 2003. Therefore measurements from the pluviometers outside the catchment were used as input-data. The high spatial variability of rainfall events caused poor simulation of certain events. This is documented by the rainfall event of 15 August 2003, where the highest discharge peak of the year was measured while nearly no precipitation was recorded by the pluviometers. Consequently the model underestimates the discharge for this event. Concerning the representation of the base-

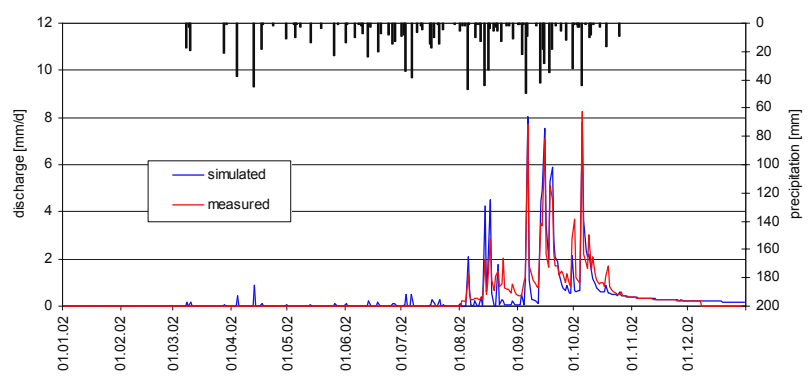

Fig. 8. Comparison of the simulated and measured hydrograph of the Lower Aguima catchment, year $2002\left(16.5 \mathrm{~km}^{2}\right.$, validation result, proxi-basin test).

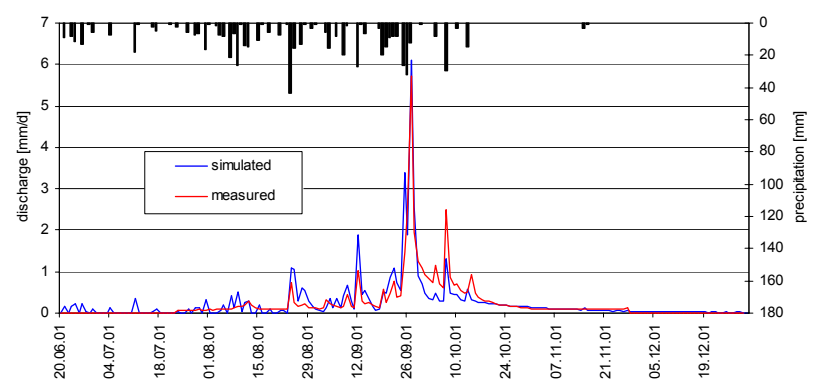

Fig. 9. Comparison of the simulated and measured hydrograph of the Lower Aguima catchment, year $2001\left(16.5 \mathrm{~km}^{2}\right.$, validation result, proxy-basin and split-sample test).

flow the simulation shows good results. The model efficiency $(0.64)$ and the $\mathrm{r}^{2}(0.67)$ are lower than for the years 2001 and 2002.

Further validation of discharge was performed for the Upper Aguima catchment (2001 and 2003) and for the Upper Niaou catchment (2001-2003). The results are summarized in Table 6. Comparable to the validation in the Lower Aguima catchment best results were obtained for the year 2002. Due to the uncertainties of the precipitation data the model performance is lower in 2003.

\subsubsection{Validation of discharge components}

As explained in Sect. 5.2 the water analysis data of Fass (2004) were used to validate the discharge components.

The following mixing-ratio was determined by Fass (2004):

- $73 \%$ surface water and soil water

- $25 \%$ groundwater of the saprolitic zone

$-2 \%$ deep groundwater

This ratio is an average value for all rivers of the catchment. Due to the low sampling number, a determination of the ratio for each river was not feasible. 
Table 7. Simulated discharge components [\%].

\begin{tabular}{llllllll}
\hline & \multicolumn{2}{l}{ Upper Aguima } & Lower Aguima & Upper Niaou & Mean \\
\cline { 2 - 8 } & 2001 & 2002 & 2001 & 2002 & 2001 & 2002 & $2001+2002$ \\
\hline Surface runoff & 14 & 15 & 8 & 10 & 24 & 13 & 14 \\
Interflow & 64 & 59 & 43 & 39 & 58 & 67 & 55 \\
Groundwater & 22 & 26 & 48 & 51 & 18 & 20 & 31 \\
\hline
\end{tabular}

Table 8. Measured (= determined with Eq. 12) and simulated surface runoff for the Upper Aguima and the Upper Niaou catchments for runoff events in the rainy season 2002.

\begin{tabular}{|c|c|c|c|c|c|c|}
\hline & \multicolumn{3}{|c|}{ Upper Aguima } & \multicolumn{3}{|c|}{ Upper Niaou } \\
\hline & $\begin{array}{l}\text { Discharge } \\
{[\mathrm{mm}]}\end{array}$ & $\begin{array}{l}\text { Surface runoff } \\
\text { measured } \\
{[\%]}\end{array}$ & $\begin{array}{l}\text { Surface runoff } \\
\text { simulated } \\
{[\%]}\end{array}$ & $\begin{array}{l}\text { Discharge } \\
{[\mathrm{mm}]}\end{array}$ & $\begin{array}{l}\text { Surface runoff } \\
\text { measured } \\
{[\%]}\end{array}$ & $\begin{array}{l}\text { Surface runoff } \\
\text { simulated } \\
{[\%]}\end{array}$ \\
\hline 24 Aug 2002 & 1.18 & 26.1 & 38.4 & 6.85 & 22.0 & 0 \\
\hline 29 Aug 2002 & 0.71 & 16.8 & 80.6 & n.a. & n.a. & n.a. \\
\hline 3 Sep 2002 & 2.19 & 30.4 & 51.6 & n.a. & n.a. & n.a. \\
\hline 5 Sep 2002 & 12.02 & 40.8 & 52.6 & 14.01 & 34.8 & 31.2 \\
\hline 15 Sep 2002 & 8.37 & 32.5 & 9.2 & 10.11 & 31.9 & 36.5 \\
\hline 19 Sep 2002 & n.a. & n.a. & n.a. & 5.05 & 11.8 & 42.49 \\
\hline 21 Sep 2002 & n.a. & n.a. & n.a. & 1.48 & 7.7 & 0 \\
\hline 27 Sep 2002 & 2.65 & 30.5 & 30.8 & n.a. & n.a. & n.a. \\
\hline 5 Oct 2002 & 1.30 & 18.7 & 11.7 & n.a. & n.a. & n.a. \\
\hline 9 Oct 2002 & 2.99 & 21.1 & 8.7 & n.a. & n.a. & n.a. \\
\hline 11 Oct 2002 & 1.65 & 17.2 & 5.4 & n.a. & n.a. & n.a. \\
\hline 19 Oct 2002 & 2.75 & 31.8 & 26.6 & n.a. & n.a. & n.a. \\
\hline 25 Oct 2002 & 0.56 & 18.7 & 30.4 & n.a. & n.a. & n.a. \\
\hline
\end{tabular}

n.a.: no data available

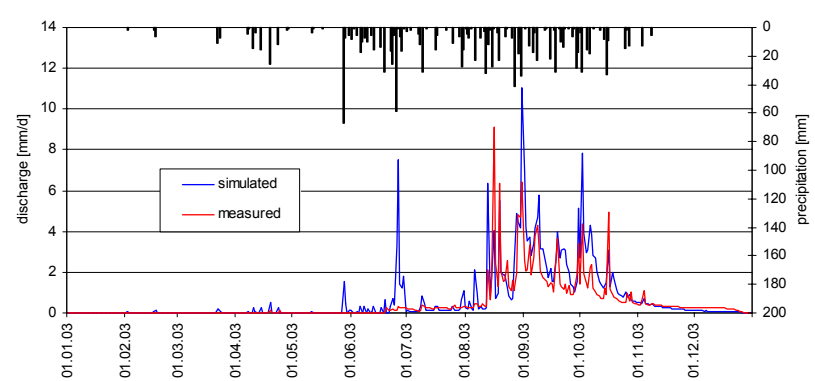

Fig. 10. Comparison of the simulated and measured hydrograph of the Lower Aguima catchment, year $2003\left(16.5 \mathrm{~km}^{2}\right.$, validation result, proxi-basin and split-sample test).

The simulated discharge components of SIMULAT-H for the different river gauges are shown in Table 7 for the years 2001 and 2002. The simulated groundwater ratio for all considered gauges of $31 \%$ is very close to the ratio determined by the hydrochemical measurements $(27 \%)$. Consequently the correspondence of the modelled and measured surface and soil water fraction is also good.
Additionally a validation of the discharge components was performed for single events based on continuous measurements of electric conductivity of the river water during the rainy season 2002. The separation of surface runoff from the baseflow was calculated with the following equation:

$q r=(c d-c b) \cdot \frac{q d}{(c p-c b)}$

with

$q r=$ surface runoff $[1 / \mathrm{sec}]$

$q d=$ river discharge $[1 / \mathrm{sec}]$

$c d=$ electric conductivity of the river discharge $[\mu \mathrm{s} / \mathrm{cm}]$

$c b=$ electric conductivity of the baseflow $[\mu \mathrm{s} / \mathrm{cm}]$

$c p=$ electric conductivity of the precipitation $[\mu \mathrm{s} / \mathrm{cm}$ ]

The calculation of the surface runoff amount based on the electric conductivity is not always precise, because the conductivity of the river discharge can also be reduced by the quick subsurface flow, which has lower conductivity than the baseflow. 


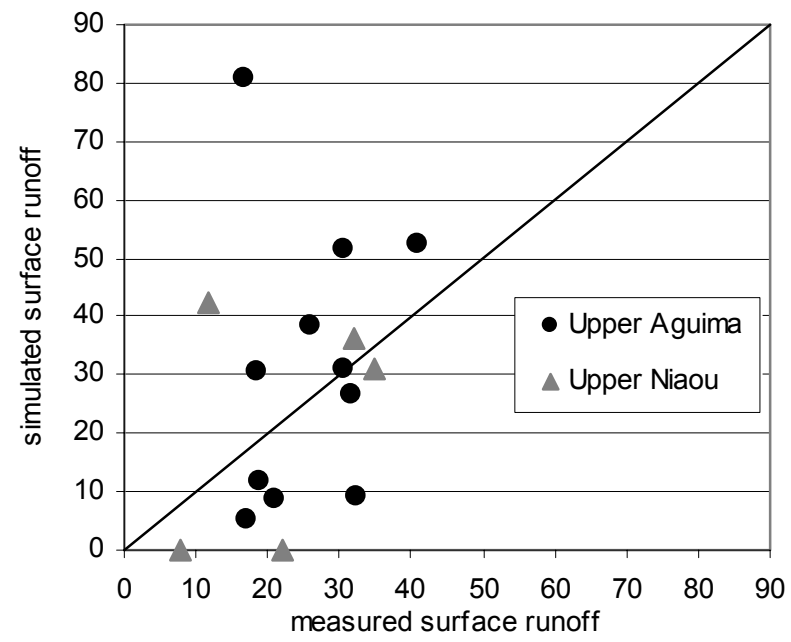

Fig. 11. Scatter plot of simulated and measured (= determined with Eq. 12) surface runoff for the Upper Aguima $\left(3.2 \mathrm{~km}^{2}\right)$ and the Upper Niaou $\left(3.1 \mathrm{~km}^{2}\right)$ for runoff events in the rainy season 2002 (in $\%$ of the total discharge).

Table 9. Validation of soil moisture at different depths for a Lixisol with woodland vegetation in the Upper Aguima catchment.

\begin{tabular}{llll}
\hline & ME & $\mathrm{r}^{2}$ & $\mathrm{IA}$ \\
\hline 2001 & & & \\
\hline $0-20 \mathrm{~cm}$ & 0.86 & 0.95 & 0.97 \\
$30-50 \mathrm{~cm}$ & 0.55 & 0.86 & 0.91 \\
$80-100 \mathrm{~cm}$ & -0.25 & 0.57 & 0.45 \\
$120-140 \mathrm{~cm}$ & 0.51 & 0.79 & 0.88 \\
\hline 2002 & & & \\
\hline $0-20 \mathrm{~cm}$ & 0.72 & 0.94 & 0.95 \\
$30-50 \mathrm{~cm}$ & 0.71 & 0.94 & 0.94 \\
$80-100 \mathrm{~cm}$ & 0.57 & 0.81 & 0.85 \\
$120-140 \mathrm{~cm}$ & 0.19 & 0.54 & 0.76 \\
\hline
\end{tabular}

Figure 11 shows the scatterplot of simulated and "measured" (=calculated with Eq. 12) surface runoff for recorded discharge peaks during the rainy season 2002. Considering all the above mentioned uncertainties, the correspondence between the simulated and "measured" surface runoff is relatively good for the Upper Aguima catchment. Only for one event the surface runoff is strongly overestimated. For the other events under- and overestimation is observable. As shown in Table 8 no dependency of the over-/underestimation on discharge amount is obvious. Due to a failure of the conductivity probes only measurements of a few peaks were available for the surface runoff validation in the Upper Niaou catchment. For the discharge events in the beginning and
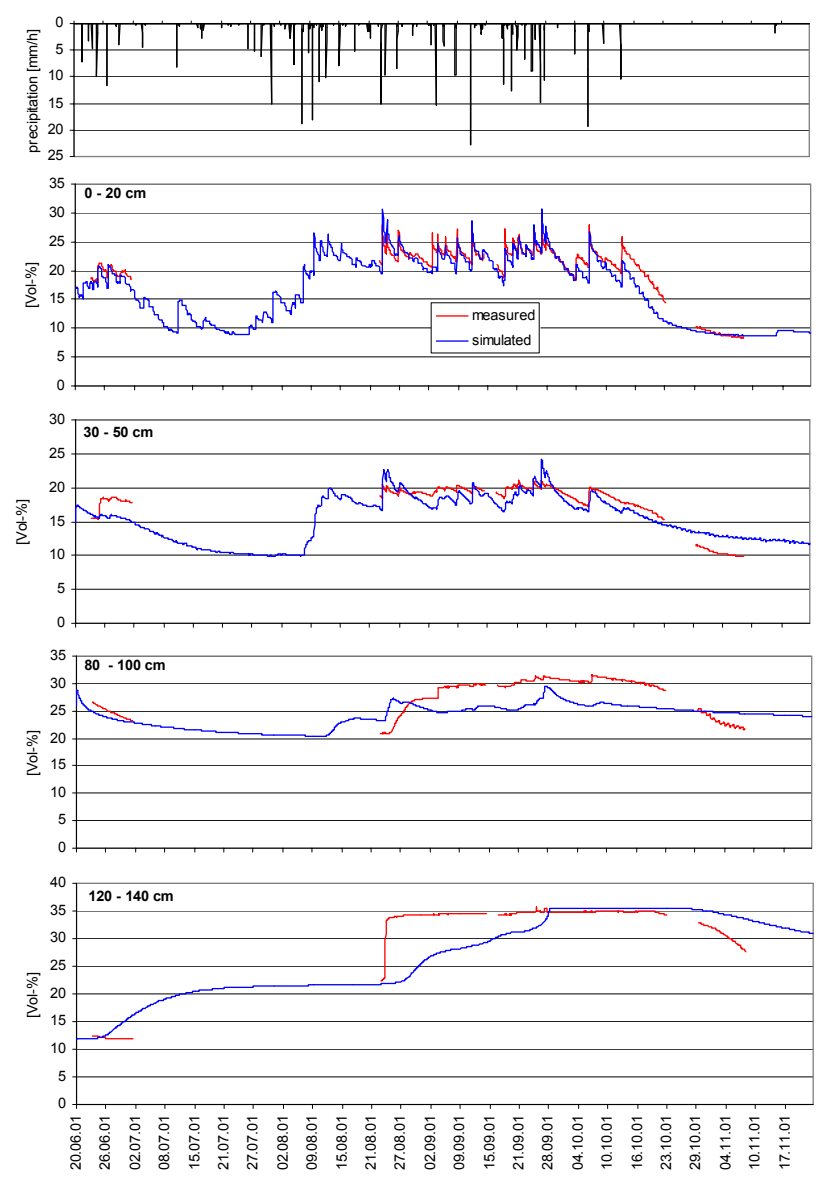

Fig. 12. Comparison of simulated and measured soil moisture at different depths for a Lixisol with woodland vegetation in the Upper Aguima catchment, year 2001 (missing data: failure of measuring system).

the middle of September the agreement is good, but for the events of the 24 August 2002 and the 21 September 2002 no surface runoff was simulated by the model, while the measurements determined surface runoff. The poor model performance for the event of the 24 August 2002 could be explained with high amount of runoff on the pathways. Although the pathways were taken into account in the simulation, the process of surface runoff flowing from fields to pathways was not considered in the model. Consequently the direct runoff from pathways to the river was underestimated. In general the model performance for the discharge is relatively poor in August (see Figs. 6 and 8).

The lack of simulated runoff on the 21 September 2002 could be explained by a failure in the precipitation input data for the simulation. For this day no rain was recorded on the rain gauge in the Upper Niaou catchment. 


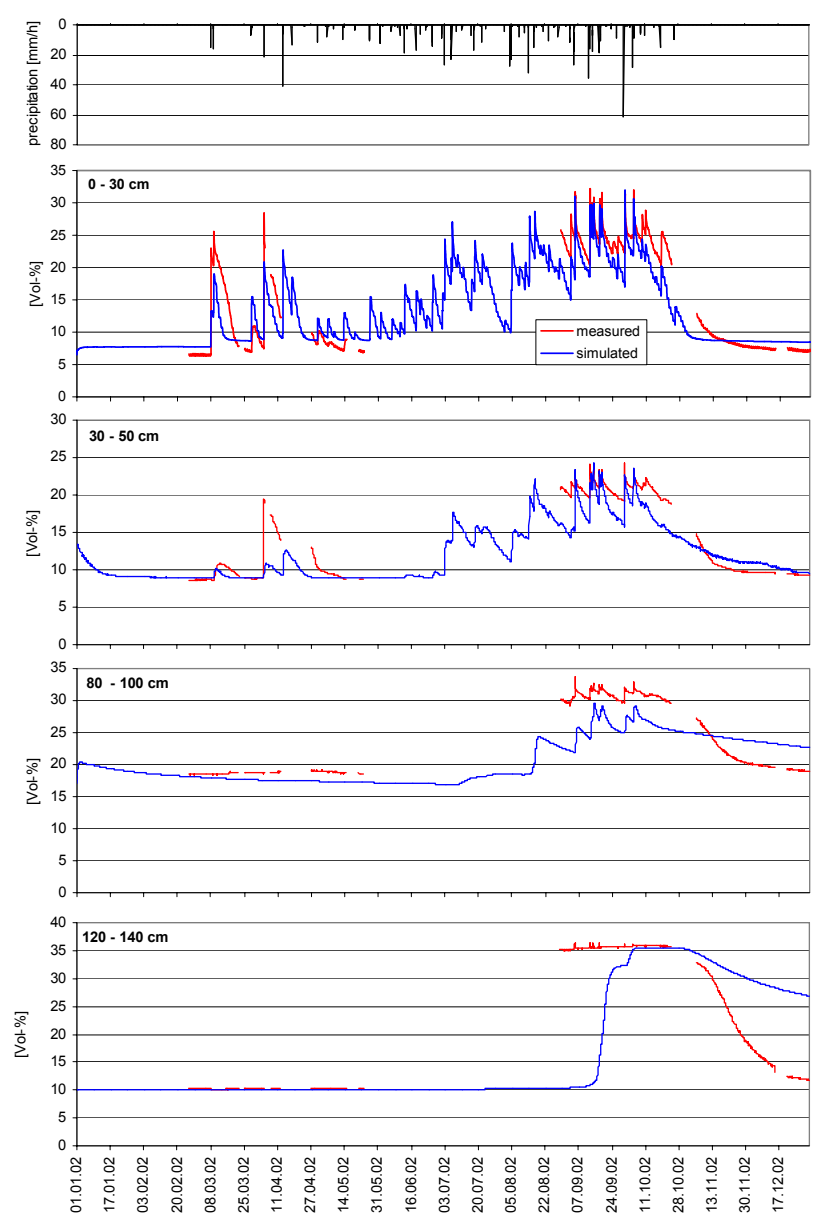

Fig. 13. Comparison of simulated and measured soil moisture at different depths for a Lixisol with woodland vegetation in the Upper Aguima catchment, year 2002 (missing data: failure of measuring system).

\subsubsection{Validation of soil moisture}

The validation of the soil moisture was carried out for the Upper Aguima catchment by comparing the simulated soil moisture of different depth with the soil moisture measurements with TDR-probes of the same depth. The validation was performed for a Lixisol with woodland vegetation for the years 2001 and 2002 as nearly no measurement values were available for 2003 due to a failure of the measuring system.

The soil hydrological parameters $\mathrm{K}_{\mathrm{sat}}, \theta \mathrm{s}, \theta \mathrm{r}$ and Brooks and Corey parameters used for the simulation were taken from measurements without additional calibration. Because the soil moisture data were not used for the calibration of the model also the data from 2002 can be used for validation. The comparison of measured and simulated soil moisture is shown in Figs. 12 and 13.

In both years the agreement between simulated and measured soil water dynamic in the depth of $0-30 \mathrm{~cm}$ is good.
The peaks as well as the drying of the soil at the end of the rainy season are simulated well. For both years the $r^{2}$ and the index of agreement are larger than 0.94 (Table 9), while a model efficiency of 0.86 for the year 2001 and of 0.72 for the year 2002 was achieved. For the layer $30-50 \mathrm{~cm}$ the model performance is lower. While the dynamic of the soil moisture is well reproduced by the model, the agreement of the simulated and measured soil moisture peaks are poorer than in the first layer. Overall the results are reasonable for this layer. As shown in Figs. 12 and 13 and in Table 9 the simulation result of the Btc-horizon $(80-100 \mathrm{~cm})$ is poor. This could be explained by the high gravel content of this layer, which causes inaccuracies in the TDR-measurements and for the determination of the soil-water-retention curve.

In the saprolitic layer $(120-140 \mathrm{~cm})$ the constant soil water content of $10 \%$ in the beginning of the rainy season is well simulated in 2002. In 2001 the saturation of the subsoil is a very rapid process, which is not simulated accurately by the model. According to the measurements the soil moisture increases from 10 to $35 \%$ during one day in 2001 , which is caused by preferential flow in continuous macropores. Calculating the amount of water required for saturating the soil in this depth it became clear that this is a local scale phenomenon. As there is no macropore-model available in SIMULAT-H the model is not able to simulate this process.

\section{Representation of the runoff generation processes}

The characterization of the major soil types with regard to the runoff generation processes in Sect. 3 has shown that the soil physical properties differs strongly for the subsoil of the dominant soil types (Plinthosol, Lixisol/Acrisol, Gleysol). The runoff generation processes based on the soil investigations and field observations are explained in Sect. 3. The model concept of SIMULAT-H allows the quantification of the runoff generation processes for each soil unit of the hillslope. Figure 14 shows the runoff generation for 2002 for one representative slope of the Upper Aguima and Fig. 15 for the Upper Niaou catchment.

In the Upper Aguima catchment interflow is the predominant runoff generation process in the major soil types of the upper and middle hillslope (Plinthosol, Lixisol/Acrisol). While for the Plinthosol no groundwater recharge was determined, about $25 \%$ groundwater recharge was calculated by the model for the soil unit Lixisol/Acrisol. For the Gleysols groundwater recharge is the major runoff generation process.

Due to the lower infiltration rates on fields (compare Giertz, 2004 and Giertz et al., 2005) the proportion of surface runoff is higher in the Upper Niaou catchment. In particular on the middle slope on Plinthosols the ratio of surface runoff of all runoff generation processes is very high. On Lixisols/Acrisols the interflow is predominant. Here the overland flow is even lower than in the Upper Aguima catchment. 


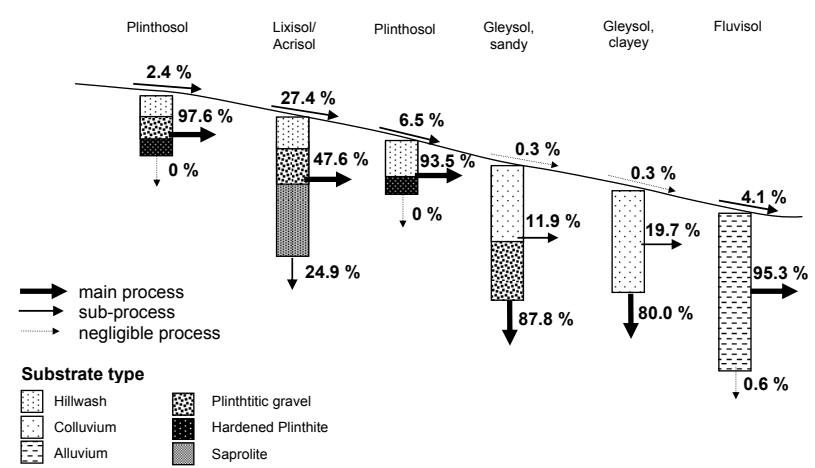

Fig. 14. Simulated runoff generation processes [\%] for a representative hillslope of the Upper Aguima catchment (natural vegetation).

This is caused by the extremely high saturated conductivity which was determined for a cashew plantation in the Upper Niaou on this soil type (Giertz and Diekkrüger, 2003).

Concerning the runoff generation processes the simulation results confirm the findings of the field measurements presented in perceptual model in Sect. 3. The major runoff generation process on the upper and middle hillslope of the Upper Aguima catchment is interflow, which was determined by the simulation and the perceptual model. Dependent on the land cover, surface runoff or interflow are predominant for Plinthosols and Lixisols/Acrisols for the same slope section. At the bottom of the slope groundwater recharge is an important process, due to high permeability of the Gleysols. In the Upper Niaou also surface runoff occurs due to a high amount of surface runoff from the upper slope soil units.

\section{Discussion of uncertainties}

Generally three sources of uncertainties in the modelling process can be distinguished:

1. Input parameter

2. Model assumptions and algorithms for process description

\section{Measuring data for model validation}

\subsection{Input parameter}

Due to the interdisciplinary research in the Aguima catchment, the database to parameterize the model was very good for West African conditions. Consequently the uncertainties related to the input parameters are relatively low.

Concerning vegetation parameters measurement data of LAI and vegetation height were available from studies of Orthmann (2005) and Mulindabigwi (2005). The LAI measurements of the natural vegetation of Orthmann (2005) were carried out with hemispherical photographs. With this technique only the LAI of the canopy can be estimated. Therefore

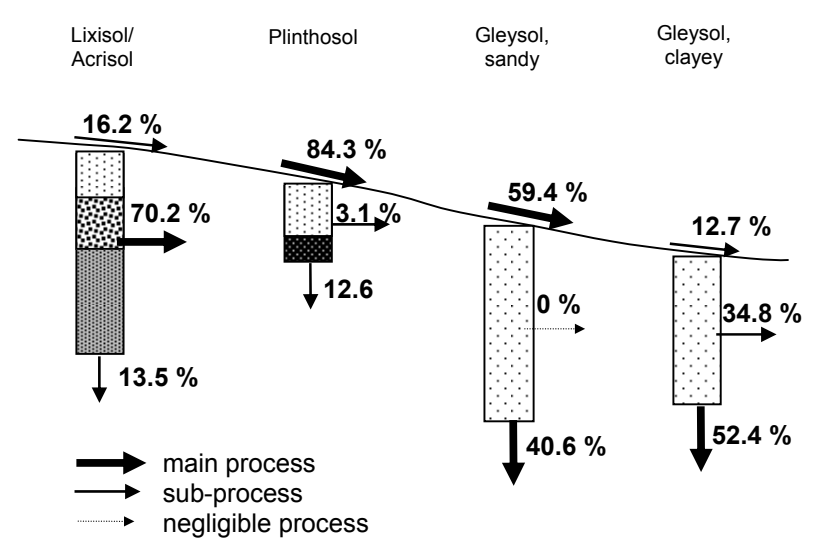

Fig. 15. Simulated runoff generation processes [\%] for a representative hillslope of the Upper Niaou catchment (agriculture). Explanation of the substrate types in Fig. 14.

a correction was necessary for vegetation types with a dense herb layer using mainly data from Scourlock et al. (2001). In general the estimation of the LAI for vegetation units is problematic in hydrologic modelling. But the sensitivity analysis showed that the impact of this parameter on the output of the model is relatively low.

The stomata resistance was taken from literature data. As the sensitivity for this parameter is relatively high (see Tab. 4), the uncertainty caused by these parameters is relatively high compared to the other parameters.

The spatial distribution of the land cover types was taken from the land cover classification of Landsat ETM scenes by Judex (2003). Due to detailed ground-truth data the quality of the classification is very good for West African conditions. Because of the high heterogeneity of the vegetation types it is very difficult to carry out a classification in this region. Especially for agricultural area a distinction between different crops in the Landsat image is not feasible because of mixed cultivation and very small size of fields. Therefore only one agricultural class was defined. The characterisation of one land cover class with one parameter set is problematic because of the high heterogeneity of the land cover within one class.

Soil physical parameters were available from in-situ and laboratory measurements (Giertz, 2004, Junge, 2004, Giertz et al., 2005). In total 123 in-situ and 335 laboratory measurements were carried out for the determination of the saturated conductivity, which can vary significantly in space. Due the high spatial variability of this parameter the infiltration process within one soil unit cannot be simulated accurately using one mean value for each hillslope unit. The approach of SIMULAT-H to cope with this problem is to use a certain number of $\mathrm{K}_{\text {sat }}$-values for each soil unit, which are determined with the Latin-Hypercube method from a log-normal distribution (see Sect. 4.2) considering the mean and the standard deviation defined by the user. 
As the lateral saturated conductivity is very difficult to determine and no literature data were available this parameter was calibrated by comparing the measured and simulated hydrograph. In general it is assumed that the lateral $\mathrm{K}_{\mathrm{sat}}$ is lower than the vertical because the formation of macropore system is more vertically oriented. With calibration of the lateral saturated conductivity a reduction factor of 0.1 in relation to the vertical $\mathrm{K}_{\text {sat }}$ was determined. It is difficult to assess if this factor is correct because no measurements are available. But the simulated processes seemed to be reasonable compared to the observed hydrologic processes in the catchment. The sensitivity analysis revealed that the influence of the lateral $\mathrm{K}_{\mathrm{sat}}$ on the discharge amount is relatively low. Regarding the discharge components the influence of this parameter can be of higher importance.

The highest sensitivity index was determined for the saturated water content. But as this parameter was measured on soil cores and the spatial variability of this parameter is low compared to the saturated conductivity the uncertainty related with this parameter is relatively low.

As climate data was available from measurements in the catchment, the uncertainties related to this data are low. For West African conditions the existence of 3 climatic stations in a small basin of $30 \mathrm{~km}^{2}$ is exceptional. Only six climatic stations of the national meteorological service exist for entire Benin.

Due to a failure of the measuring system more uncertainties are related to the precipitation data for 2003, because data from rain gauges outside the catchment had been used as model input.

For the groundwater parameters no measurement data was available, hence these parameters were calibrated for the catchment. The sensitivity analysis pointed out that the influence of these parameters on the model result is low.

9.2 Model assumptions and algorithms for process description

In general the model related uncertainties are lower for physically-based models than for conceptual or empirical models. As pointed out in Sect. 8, SIMULAT-H is able to correctly simulate the runoff generation processes in the catchment. Therefore it can be assumed that the uncertainties related to the process description in general are low. But the validation of the soil moisture revealed that some details such as the saturation of the sub-soil are not correctly simulated by the model. This is caused by the lack of a macropore model in SIMULAT-H. As macropores play an important role for soil water fluxes in the catchment (Giertz, 2004; Giertz et al. 2005), neglecting the macropores can cause a poorer representation of the processes. An integration of this could ameliorate the model performance.

Another model related uncertainty is the lack of a routingroutine in SIMULAT-H. As the results were validated on a daily time step and the regarded catchments are small, the inaccuracy caused by this is relatively small. For the validation of single events as performed in Vertessy and Elsenbeer (1999) the lack of a routing-routine would have a stronger influence on the model result.

The analysis of the hydrologic processes revealed that the process of reinfiltration of the surface runoff within one hillslope is significant in the Aguima catchment (Giertz, 2004). The importance of this process was also observed by van de Giesen et al. (2000) in a catchment in central Côte d'Ivoire. In order to take this process into account the hillslope approach was integrated in SIMULAT-H. Reinfiltration can also occur within the same hillslope-unit, which is not implied in the model. But the high spatial variability of the infiltration process is taken into account using multiple $\mathrm{K}_{\text {sat }^{-}}{ }^{-}$ values for the calculation of the infiltration rate.

As already mentioned in Sect. 7 the poor representation of surface runoff generation on pathways is one model related uncertainty. Most of all the process of surface runoff running from fields on the pathways is poorly represented in the model. But it has to be noticed that parameterization is difficult to perform because these pathways are spontaneously built by the local farmers.

Although the model SIMULAT-H implies some simplifications in the process description the process representation is quite good, as shown in Sect. 7.

\subsection{Measuring data for model validation}

Compared to other studies, the database for model validation was good, as in addition to discharge also discharge components and soil moisture data were available for model validation.

In general all measurements contain measurement errors, which have to be taken into account while using this data for validation.

\section{Discharge data}

The discharge was calculated based on continuous water level measurements and a stage-discharge relationship for each gauge. The latter was obtained by numerous discharge measurements in 2001 and 2002 with the cross section method (Davie, 2003) at different water levels. Although this method is related with uncertainties, it is the standardmethod for discharge measurements, because other methods for continuous discharge measurements are not available.

One uncertainty of this method is the possible change in the morphology of the riverbed caused by erosion and sedimentation processes, which can influence the stage-discharge relationship.

Another problem is that often during peak discharge no discharge measurements were carried out or the measurements were difficult to perform (e.g. because of inundation of the river bank). To calculate the peak-discharge based on the stage-discharge relationship an extrapolation was performed. 
Consequently the calculated peak discharge is very uncertain.

As shown in Sect. 8 the representation of the peak discharge is very good for the year 2002. In 2003, no additional discharge measurements were carried out to complete the stage-discharge relationship. Consequently for this year higher uncertainties concerning the discharge data are expectable.

The validation of simulated surface runoff of single peaks was performed using measurement data of electric conductivity. The calculation of the surface runoff from the conductivity data is based on Eq. (12). The assumption is that the conductivity of the discharge is a mixture of baseflow and surface runoff, which has a lower conductivity as the baseflow. The uncertainty in this assumption is that in addition to the surface runoff, the quick interflow can reduce the electric conductivity of the discharge. But if the residence time of the water in the soil is low or if the water runs in macropores to the river the electric conductivity is comparable with the surface runoff.

\section{Soil moisture}

TDR-probes are a standard measuring instrument for the determination of soil moisture. The accuracy of the soil moisture measurements is very high, with the exception of soils with a very high humus content, salinity or density. Measurement errors also occur when the contact between the soil matrix and the probe is poor. This is often the case in soils with high gravel content. As the sub-soil of the Lixisol, where the measurements of soil moisture were carried out in the Aguima catchment, is characterized by a high gravel content, the possible measurement error has to be taken into account when using this data for model validation. The comparison of simulated and measured soil moisture in this layer has shown a poor agreement. One reason for this could be possible errors in the measurement data as explained before.

The discussion of the uncertainties pointed out that at all levels (input data, model assumptions and validation data) uncertainties exist. Often it is not possible to determine which uncertainties cause the deviation between modelled and measured state variables. By calibration often uncertainties are reduced due to the wrong reason. Because in this study only two parameters have been calibrated, the uncertainties were better identifiable.

\section{Conclusions}

The validation of the physically-based model SIMULAT-H has shown that the model concept is suitable to simulate the hydrological processes in a tropical environment. For the discharge validation good results were achieved for dry and wet years. Main differences were observable in the beginning of the rainy season. This was also observed for application of other hydrological models in similar climate conditions (Campling et al., 2002; Varado, 2004).

The comparison of the discharge components determined by hydrochemical measurements with the simulation revealed that the model simulated the ratio of groundwater and surface water correctly. For the validation of the discharge components of single events larger differences were observable, which was partly caused by uncertainties in the precipitation data. For one event the reason for the lack of surface runoff was rather the insufficient representation of the runoff generation processes on pathways. First modifications of the modelling process have shown that the assumption that a higher proportion of surface runoff flows directly into the river instead of running on the next soil unit ameliorates the simulation results.

Concerning soil water dynamics the model performance was good for the topsoil. Major problems occurred in the gravel-enriched Btc-horizon. Due to the high gravel content the uncertainties in the measurements of the soil physical parameters are high (e.g. $\mathrm{K}_{\text {sat }}$ measurements, determination of soil water retention curve) and also the installation of TDR-probes in the soil is difficult. Both could be reasons for the big differences between the measured and simulated soil moisture. In the saprolitic horizon the model was not able to reproduce the quick saturation of this layer, because no macropore model is available in SIMULAT-H. An integration of macropores in the modelling system could ameliorate the model performance concerning the soil water dynamics. But in general the parameterization of a macropore-system is very difficult, because often no information about the size, the amount and the continuity of macropores is available. Another problem is that the measured $\mathrm{K}_{\text {sat }}$-values include marcropore-flow, so that they are not usable to parameterize a model with an additional macropore system without further assumptions.

Although the model SIMULAT-H implies some simplifications in the process description the model is able to simulate the processes correctly, which was revealed by a comparison with the field observations.

With the application of a physically-based model in Benin this study is a relevant contribution to the research domain of hydrological modelling in tropical regions, especially West Africa. Due to the limited data availability often only conceptual models are applied and the experience with physically-based models in this region is low.

The multi-criteria validation for catchments with different land use and for dry and wet years has shown that the presented model is applicable for calculating future scenarios of land use and climate change in tropical regions in order to predict the impact of these changes on the hydrological processes and water availability at the local scale. Furthermore the model can be used for a model to model comparison in Global Change studies to evaluate the scenario simulation results of conceptual models for larger scales. 
Acknowledgements. The authors would like to thank the German ministry of education and research (BMBF, grant No. 01 LW 0301A) as well as the MSWF Northrine-Westfalia (Grant No. 223-21200200) for the funding of the IMPETUS project in the framework of the GLOWA program. Thanks also to all colleagues of the IMPETUS-project, who provides data for the model parameterization and validation.

Edited by: S. Uhlenbrook

\section{References}

Andersen, J., Refsgaard, J. C., and Jensen, K. H.: Distributed hydrological modelling of the Senegal river basin - model construction and validation. J. Hydrol., 247, 200-214, 2001.

Bonell, M. and Bruijnzeel, L. A. (Eds.): Forests, Water and People in the Humid Tropics. Past, Present and Future Hydrological Research for Integrated Land and Water Management, Cambridge University Press, 2005.

Bormann, H. and Diekkrüger, B.: A conceptual, regional hydrological model for Benin (West Africa): validation, uncertainty analysis and assessment of applicability for environmental change analyses, Phys. Chem. Earth, 29, 759-786, 2004.

Brooks, R. H. and Corey, A. T.: Hydraulic properties of porous media, in: Hydrology Paper 3, Colorado State University, Fort Collins, Colorado, 22-27, 1964.

Campling, R., Gobin, A., Beven, K., and Feyen, J.: Rainfall-runoff modelling of a humid tropical catchment: the TOPMODEL approach, Hydrol. Processes, 16, 231-253, 2002.

Chevallier, P. and Planchon, O.: Hydrological processes in a small humid savanna basin, J. Hydrol., 151, 173-191, 1993.

Cournac, L., Dubois, M.-A., Chave, J., and Riéra, B.: Fast determination of light availability and leaf area index in tropical forests, J. Tropical Ecol., 18, 295-302, 2002.

Dagbenonbakin, G. D.: Crop productivity and water use efficiency of important crops in the Upper Ouémé Catchment, $\mathrm{PhD}$-Thesis University of Bonn, http://hss.ulb.uni-bonn.de/diss _ online/landw_fak/2005/dagbenonbakin_gustave/, 2005.

Davie, T.: Fundamentals of Hydrology, Routledge London, 2003.

de Roo, A. D. J.: Modelling surface runoff and soil erosion in catchments using geographical information systems, Validity and applicability of the "ANSWERS" model in two catchments in the loess area of South Limburg (the Netherlands) and one in Deven (UK). Netherlands Geographical Studies 157, 1993.

de Wasseige, C., Bastin, D., and Defourny, P.: Seasonal variation of tropical forest LAI based on field measurements in Central African Republic, Agric. Forest Meteorol., 119, 181-194, 2003.

Diekkrüger, B. and Arning, M.: Simulation of water fluxes using different methods for estimating soil parameters, Ecol. Modell., 81, 83-95, 1995.

Elsenbeer, H, Cassel, K., and Castro, J.: Spatial Analysis of Soil Hydraulic Conductivity in a Tropical Rain Forest Catchment, Water Resour. Res., 28, 3201-3214, 1992.

Elsenbeer, H. and Lack, A.: Hydrometric and hydrochemical evidence for fast flow-paths at La Cuenca, Western Amazonia, J. Hydrol., 180, 237-250, 1996.

Elsenbeer, H. and Vertessy, R. A.: Stormflow generation and flowpath characteristics in an Amazonian rainforest catchment, Hy- drol. Processes, 14, 2367-2381, 2000.

Fairchild, J. and Leymarie, P.: Drainage networks from grid digital elevation models, Water Resour. Res., 27(3), 709-717, 1991

Fass, T.: Hydrogeologie im Aguima-Einzugsgebiet, Benin, West Afrika. PhD-Thesis University of Bonn, http://hss.ulb.uni-bonn. de/diss_online/math_nat_fak/2004/fass_thorsten, 2004.

Feddes, R. A., Kowalik, P. J., and Zaradny, H.: Simulation of field water use and crop yield. Simulations Monograph, Pudoc, Wageningen, 1978.

Garbrecht, J. and Martz, L. W.: TOPAZ: An automated digital landscape analysis tool for topographic evaluation, drainage identification, watershed segmentation and subcatchment parameterization. TOPAZ user manual. U.S. Department of Agriculture, ARS Publication GRL 97 (4), El Reno, Oklahoma, 1997.

Giertz, S. and Diekkrüger, B.: Analysis of the hydrological processes in a small headwater catchment in Benin (West Africa), Phys. Chem. Earth, 28, 1333-1341, 2003.

Giertz, S.: Analyse der hydrologischen Prozesse in den subhumiden Tropen Westafrikas unter besonderer Berücksichtigung der Landnutzung am Beispiel des Aguima-Einzugsgebietes in Benin. PhD-Thesis University of Bonn, http://hss.ulb.uni-bonn. de/diss_online/math_nat_fak/2004/giertz_simone/index.htm, 2004.

Giertz, S., Junge, B., and Diekkrüger, B.: Assessing the effects of land use change on soil physical properties and hydrological processes in the sub-humid tropical environment of West Africa, Phys. Chem. Earth, 30, 485-496, 2005.

ISSS Working Group RB: World Reference Base for Soil Resources: Introduction, Acco, Leuven, 1998.

Jeje, L. K., Ogundoya, O. O., and Uyi, O. E.: Subsurface fow from a forested slope in Ife area of southwestern Nigeria, Hydrol. Sci. J., 31, 584-594, 1986.

Judex, M.: Analyse und Erklärung der Landbedeckungsund Landnutzungsänderung im Upper Oueme Catchment (Benin, Westafrika) durch die Verknüpfung von LANDSAT-Daten mit sozioökonomischen Daten. Diploma thesis, Geographical Institute, University of Bonn, http://www.rsrg.uni-bonn.de/RSRGwww/Deutsch/ Diplomarbeiten/Judex_Diplomarbeit_2003.pdf, 2003.

Junge, B.: Die Böden im oberen Ouémé-Einzugsgebiet: Pedogenese, Klassifikation, Nutzung und Degradierung. PhDThesis University of Bonn, http://hss.ulb.uni-bonn.de/diss online/landw_fak/2004/junge_birte/index.htm, 2004.

McKay, M. D., Beckman, R. J., and Conover, W. J.: A comparison of three methods for selecting values of input variables in the analysis of output from a computer code, Technometrics, 21, 239-245, 1979.

Mulindabigwi, V.: Influence des systèmes agraires sur l'utilisation des terroirs, la séquestration du carbone et la sécurité alimentaire dans le bassin versant de l'Ouémé supérieur au Bénin, $\mathrm{PhD}$ Thesis University of Bonn, 2005.

Nash, J. E. and Sutcliffe, J. V.: River flow forecasting through conceptual models part I - a discussion of principles, J. Hydrol., 10, 282-290, 1970.

Ogunkoya, O. O. and Jenkins, A.: Analysis of storm hydrograph and flow pathways using there-component hydrograph separation model, J. Hydrol., 97, 23-32. 1993.

Orthmann, B.: Vegetation ecology of a woodland-savannah mosaic in central Benin (West Africa): Ecosystem analysis with a 
focus on the impact of selective logging. PhD-Thesis University of Rostock, http://www.impetus.uni-koeln.de/impetus.php? show $=$ De_Pu_Ja, 2005.

Parkhurst, D. L. and Appello, C. A. J.: User's guide to PHEREEQ (Version 2) - a computer program for speciation, batch-reaction, one-dimensional transport, and inverse geochemical calculations. US Geological Survey, Water Resources Investigations Report 99-4259, 1999.

Ritchie, J. T.: A model for predicting evaporation from a row crop with incomplete cover, Water Resour. Res., 8, 1204-1213, 1972.

Refsgaard, J. C. and Storm, B.: Construction, Calibration and Validation of Hydrological Models, in: Distributed Hydrological Modelling, edited by: Abbott, M. B. and Refsgaard, J. C., Kluwer, Dordrecht, 41-54, 1996.

Scurlock, J. M. O., Asner, G. P., and Gower, S. T.: Global Leaf Area Index Data from Field Measurements, 1932-2000. The Oak Ridge National Laboratory Distributed Active Archive Center, Oak Ridge, Tennessee, USA, 2001.

Smith, R. E. and Parlange, J.-Y.: A parameter-efficient hydrologic infiltration model, Water Resour. Res., 14, 533-538, 1978.

Sobieraj, J. A., Elsenbeer, H., Coelho, R. M., and Newton, B.: Spatial variability of soil hydraulic conductivity along a tropical rainforest catena, Geoderma, 108, 79-90, 2002.
Speth, P., Diekkrüger, B., and Christoph, M.: IMPETUS West Africa. An integrated approach to the efficient management of scare water resources in West Africa - case studies for selected river catchments in different climatic zones. GLOWA Status Report 2002, 61-67, http://www.impetus.uni-koeln.de/impetus. php?show=De_Pr_Do, 2002.

Van de Giesen, N., Stomph, T. J., and de Ridder, N.: Scale effects of Hortonian overland flow and rainfall - runoff dynamics in a West African catena landscape, Hydrol. Processes, 14, 165-175, 2000.

Varado, N.: Contribution au développement d'une modélisation hydrologique distribuée. Application au bassin versant de la Donga, au Bénin, http://www.lyon.cemagref.fr/doc/these/varado/index. shtml, 2004.

Vertessy, R. A. and Elsenbeer, H.: Distributed modelling of storm flow generation in an Amazonian rain forest catchment: Effects of model parameterization, Water Resour. Res., 35, 2173-2187, 1999.

Vertessy, R. A., Elsenbeer, H., Bessard, Y., and Lack, A.: Storm Runoff Generation at La Cuenca, in: Spatial Patterns in Catchment Hydrology: Observations and Modelling, edited by: Grayson, R. and Blöschl, G., Cambridge University Press, 247271, 2000.

Willmott, C. J.: On the validation of models, Phys. Geogr., 1, 184194, 1981. 